\title{
Recent progress of iPSC technology in cardiac diseases
}

\author{
Shunsuke Funakoshi ${ }^{1,2} \cdot$ Yoshinori Yoshida ${ }^{1,2}$ (1) \\ Received: 1 September 2021 / Accepted: 29 September 2021 / Published online: 17 October 2021 \\ (c) The Author(s), under exclusive licence to Springer-Verlag GmbH Germany, part of Springer Nature 2021
}

\begin{abstract}
It has been nearly 15 years since the discovery of human-induced pluripotent stem cells (iPSCs). During this time, differentiation methods to targeted cells have dramatically improved, and many types of cells in the human body can be currently generated at high efficiency. In the cardiovascular field, the ability to generate human cardiomyocytes in vitro with the same genetic background as patients has provided a great opportunity to investigate human cardiovascular diseases at the cellular level to clarify the molecular mechanisms underlying the diseases and discover potential therapeutics. Additionally, iPSCderived cardiomyocytes have provided a powerful platform to study drug-induced cardiotoxicity and identify patients at high risk for the cardiotoxicity; thus, accelerating personalized precision medicine. Moreover, iPSC-derived cardiomyocytes can be sources for cardiac cell therapy. Here, we review these achievements and discuss potential improvements for the future application of iPSC technology in cardiovascular diseases.
\end{abstract}

Keywords Induced pluripotent stem cells $\cdot$ Cardiomyocyte $\cdot$ Disease modeling $\cdot$ Maturation $\cdot$ Differentiation into subtypes

\section{Introduction}

Adult human cardiomyocytes neither survive nor proliferate well when isolated from the heart in vivo. Given this, it has been difficult to establish in vitro models of human heart disease using human primary cardiomyocytes. Mouse models are used as an alternative. However, because of differences in electrophysiological properties, such as the different action potential duration and much faster heart rate, and in gene expression patterns, such as MYH6/7, these models do not fully recapitulate human heart disease (Shanks et al. 2009; Nerbonne 2004).

In 2006, mouse-induced pluripotent stem cells (iPSCs) were first generated by inducing four transcriptional factors, OCT3/4, c-MYC, SOX2, and KLF4, into mouse fibroblasts (Takahashi and Yamanaka 2006). Human iPSCs were generated the next year using the same set of transcriptional factors (Takahashi et al. 2007). Currently, human iPSCs can be generated by several methods from several cell sources

Yoshinori Yoshida

yoshinor@cira.kyoto-u.ac.jp

1 Center for iPS Cell Research and Application, Kyoto University, Kyoto 606-8507, Japan

2 Takeda-CiRA Joint Program (T-CiRA), Fujisawa 251-8555, Japan with high efficiency (Yu et al. 2009; Okita et al. 2011; Kaji et al. 2009; Woltjen et al. 2009; Seki et al. 2010; Huangfu et al. 2008). Human iPSCs show features similar to human embryonic stem cells (ESCs), such as the ability to proliferate unlimitedly and differentiate into the three germ layers, including cardiovascular cells. Therefore, as an alternative for primary cells, many researchers have applied iPSCderived cardiomyocytes (iPSC cardiomyocytes) to cardiovascular research. One of the most useful applications is disease modeling using patient iPSCs. Because iPSCs maintain the genetic background of the donor cells, in vitro iPSC cardiomyocytes provide the same genetic background as the patient.

Additionally, recent progress in gene editing technologies, such as CRISPR/Cas9, has enabled precise comparisons of disease phenotypes and responses to drugs between the patient iPSC-derived cells and genetically corrected iPSC-derived cells or sometimes between wild-type cells and wild-type cells edited to include the mutation causing the disease (Veres et al. 2014; Musunuru 2013; Smith et al. 2014; Suzuki et al. 2014). As another application of iPSC technology, iPSC cardiomyocytes together with ESCderived cardiomyocytes (PSC cardiomyocytes) are expected as optimal cell sources for cell-based therapies to treat damaged hearts. It is well documented that directly transplanted PSC cardiomyocytes engraft in the host heart and restore 

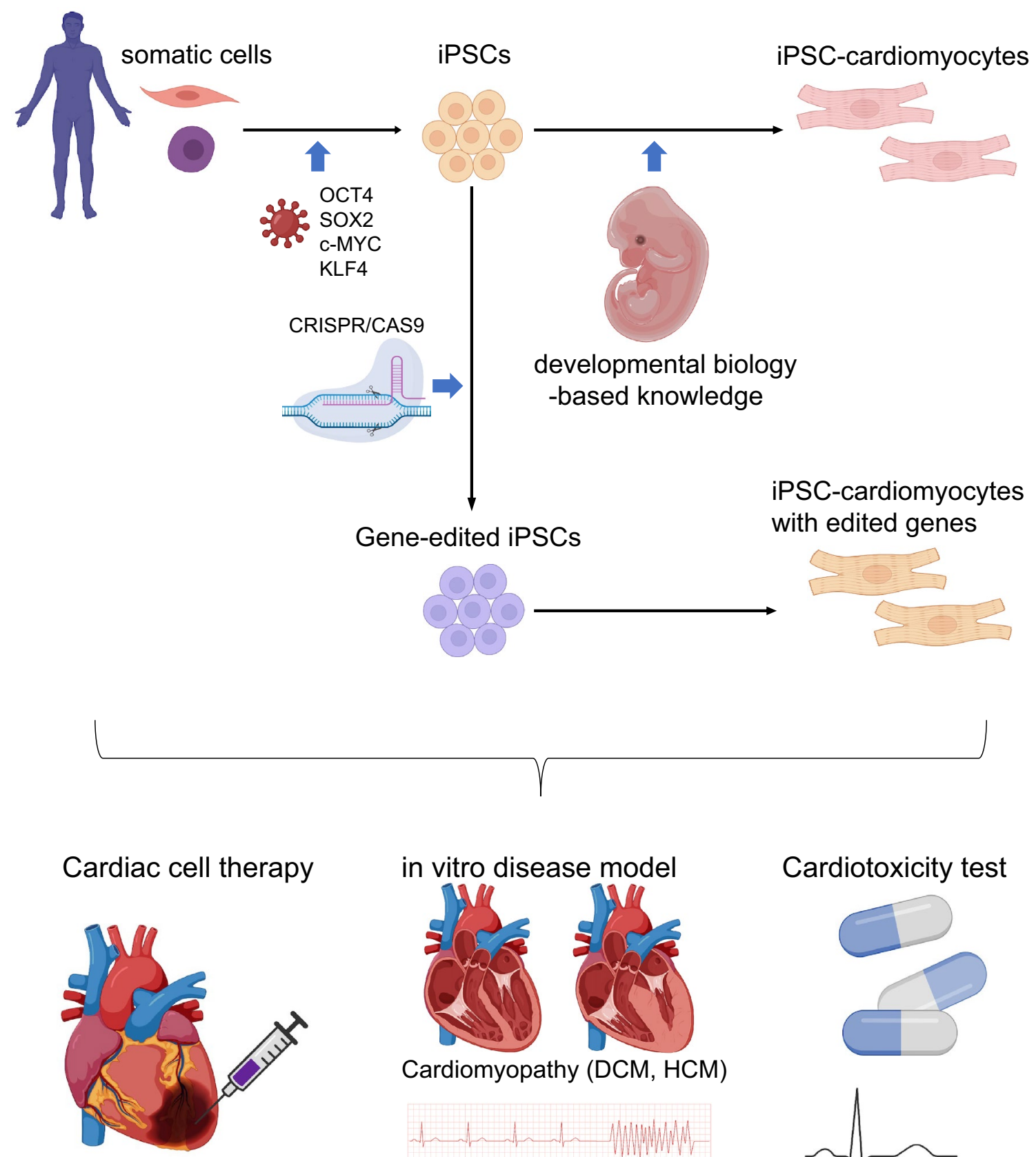

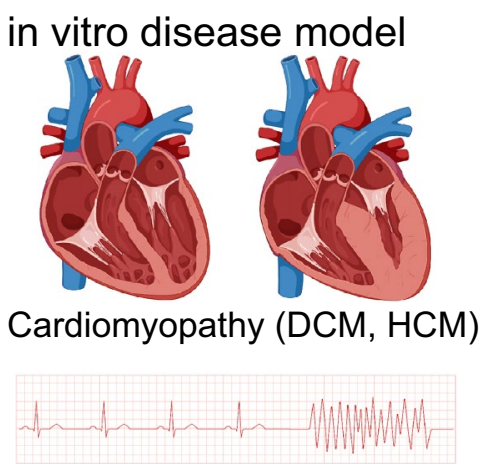

Arrhythmia disease
Cardiotoxicity test
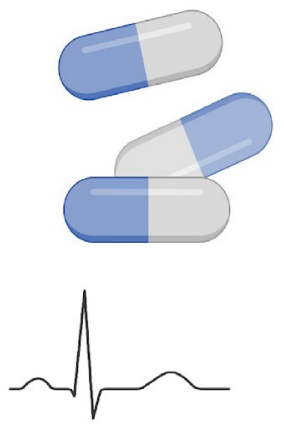

Fig. 1 Generation of iPSC cardiomyocytes and their application to cardiovascular diseases

the heart function when injected into the damaged area by mechanically contributing to the heart contraction or by paracrine effects (Laflamme et al. 2007; Chong et al. 2014; Shiba et al. 2016; Funakoshi et al. 2016; Fan et al. 2020). In addition to direct transplantation, the transplantation of cell sheets derived from PSC cardiomyocytes onto the damaged areas has also been proven to improve cardiac function in damaged hearts (Fig. 1) (Gao et al. 2018; Kawamura et al. 2017; Sekine et al. 2011).
From this perspective, we review the remarkable progress made by applying iPSC technology to cardiovascular research and discuss recent achievements and potential improvements for its clinical application. 


\section{Cardiac differentiation of iPSCs}

During the last 2 decades, researchers have developed efficient methods to differentiate PSCs into cardiomyocytes in several ways using knowledge based on heart development in vivo (Protze et al. 2019). Yang et al. could differentiate cardiac mesoderm expressing KDR and PDGFRA into cardiomyocytes by manipulating BMP and activin A/ Nodal signaling at the early stage of the differentiation, followed by inhibition of the Wnt pathway (Yang et al. 2008). Their following study revealed that individual PSC lines require optimized activin A/Nodal and BMP signaling to efficiently induce cardiac mesoderm (Kattman et al. 2011). As an alternative to BMP and activin A, Lian et al. and Burridge et al. separately developed small compound-based cardiac differentiation protocols. They both showed that a small molecule GSK3-inhibitor, CHIR99021, upregulated Wnt signaling at the early stage of the differentiation, which induced the upregulation of endogenous BMP and nodal signaling. They then added a small compound inhibiting Wnt signaling after the induction of cardiac mesoderm to produce cardiomyocytes efficiently (Lian et al. 2012; Burridge et al. 2014). In addition, researchers have developed several purification methods for PSC cardiomyocytes. For this purpose, several groups have identified cardiac-specific cell surface markers, such as SIRPA, VCAM1, and CORIN, and purified the cells by flow cytometry (Dubois et al. 2011; Uosaki et al. 2011; Zhang et al. 2019b). We developed an efficient purification method using synthetic RNA capable of sensing cardiac-specific microRNAs (Miki et al. 2015). This method is applicable to other cell types too. Tohyama et al. developed a simple method to increase the purity of PSC cardiomyocytes. They focused on differences in glucose and lactate metabolism between cardiomyocytes and nonmyocytes, including undifferentiated iPSCs, and showed that only cardiomyocytes survive in glucose-depleted culture medium containing lactate, an observation they applied to the purification of PSC cardiomyocytes (Tohyama et al. 2013). Collectively, by the combination of efficient cardiac differentiation and purification methods, researchers can generate in vitro iPSC cardiomyocytes efficiently for cardiac disease modeling, drug cardiotoxicity assays, and cardiac cell therapies.

\section{Disease modeling using iPSCs with gene mutations causing heart disease}

iPSCs share the same genetic background as the original reprogrammed cells and can differentiate into cardiomyocytes while preserving the genetic information. Therefore, by combination with gene editing technology, iPSC cardiomyocytes are useful tools to analyze the mechanism underlying a disease. In this section, we introduce some of the well-established cardiac disease models using iPSC cardiomyocytes.

\section{Channelopathy}

Long QT syndrome (LQTS) is the most common channelopathy that represents a prolongation of QT time in the electrical cardiogram and an increased risk of fatal ventricular arrhythmias. One major type of LQTS is congenital LQTS caused by mutations in ion channels, such as KCNQ1, KCNH2, and SCN5A (Wilde et al. 2021; Schwartz et al. 2012). The first LQTS disease model using patient iPSCs was reported by Moretti et al. (2010). They generated iPSCs from patients affected by LQTS type1 (LQTS1) with a KCNQ1 mutation and demonstrated that the differentiated cardiomyocytes showed a prolonged duration of the action potential compared with control iPSC cardiomyocytes. They also showed that patient iPSC cardiomyocytes had an increased susceptibility to catecholamine-induced tachyarrhythmia and that beta blockade attenuated this abnormality (Moretti et al. 2010). Following this report, several groups established LQTS1 disease models (Ma et al. 2015; Takaki et al. 2019). Wang et al. generated an iPSC-based LQTS1 disease model by overexpressing dominant-negative gene mutations of KCNQ1 using gene editing technology. They revealed that the differentiated cardiomyocytes derived from these mutants showed a prolonged action potential in response to drugs, including nifedipine and pinacidil, highlighting the strength of gene editing for iPSC-based disease modeling (Wang et al. 2014a).

In addition to LQTS1 disease models, there are numerous reports about LQTS type2 (LQTS2) disease models using iPSC cardiomyocytes from patients with $\mathrm{KCNH} 2$ mutations. Itzhaki et al. was the first to report that iPSC cardiomyocytes with $\mathrm{KCNH} 2$ mutations show a prolonged action potential with arrhythmogenicity. They also prepared an LQTS cardiac tissue model using iPSCs to evaluate responses to drugs, including potassium-channel blockers, calciumchannel blockers, $\mathrm{K}_{\mathrm{ATP}}$-channel openers, and late sodium channel blockers (Itzhaki et al. 2011). Another report by Brandao et al. generated a set of isogenic iPSC lines that possess different mutations in different sites in $\mathrm{KCNH} 2$ by genetically modifying a control iPSC line using CRISPR/ Cas9 gene editing. They demonstrated that the edited lines recapitulated the different LQTS2 mutant phenotypes and different drug responses, showing the strength of the CRISPR/Cas9 gene editing system to analyze the mechanisms underlying individual mutations causing the disease (Brandao et al. 2020). Additionally, Mehta et al. identified that lumacaftor, a drug that acts as a chaperone during 
protein folding and used clinically for patients with cystic fibrosis, significantly shortened the QT interval in LQTS2 patient iPSC cardiomyocytes (Mehta et al. 2018). Schwartz et al. tested if the in vitro results can be applied clinically to patients with LQTS2 and demonstrated that the combination of lumacaftor and ivacaftor, which is also commonly used to treat cystic fibrosis (Orkambi, Vertex Pharmaceuticals, Inc.), significantly shortened the QT interval, indicating that the drugs discovered from iPSC-based disease modeling can potentially translate clinically (Schwartz et al. 2019). Similarly, numerous studies have modeled other channelopathies, such as catecholaminergic polymorphic ventricular tachycardia (CPVT) caused by RYR2 or CASQ2 mutations and Brugada syndrome caused by SCN5A mutations (Liang et al. 2016; Jung et al. 2012; Sasaki et al. 2016; Preininger et al. 2016; Li et al. 2020). All these studies demonstrated that patient iPSC cardiomyocytes can recapitulate the diseasespecific phenotypes, such as abnormal calcium handling and triggered activity, highlighting the effectiveness of iPSCbased disease modeling for channelopathy research.

\section{Hypertrophic/dilated cardiomyopathy}

Familial cardiomyopathy is one of the most common inherited heart diseases, and hypertrophic cardiomyopathy (HCM) is one of the most common familial cardiomyopathies. An HCM heart shows ventricular wall thickening with an increased size of cardiomyocytes, a disorganized and disarrayed sarcomere, abnormal metabolism, abnormal calcium sensitivity, and arrhythmogenicity resulting in sudden cardiac death (Ashrafian et al. 2003; Maron 2018). About half of patients with HCM carry mutations in sarcomere genes, such as MYH7 and MYBPC3 (Marian and Braunwald 2017). Lan et al. first reported HCM models using iPSCs from patients with a mutation in MYH7 and demonstrated that the patient iPSC cardiomyocytes recapitulated a series of HCM phenotypes, including cellular enlargement, contractile arrhythmia, and abnormal calcium handling. They also showed that an L-type calcium blocker, verapamil, prevented the development of HCM phenotypes in the cardiomyocytes (Lan et al. 2013). Additionally, several reports have identified possible mechanisms underlying the phenotype in HCM hearts using iPSC cardiomyocytes with mutations in HCMrelated genes. Cohn et al. generated the cardiac microtissue assay to analyze iPSC cardiomyocytes from HCM patients. They demonstrated that the $\mathrm{p} 53$ pathway was activated along with increased oxidative stress and cytotoxicity due to metabolic stress in HCM cardiomyocytes and that the genetic ablation of p53 attenuated the cellular stress, indicating that the p53 pathway can be a therapeutic target in HCM heart (Cohn et al. 2019). Tanaka et al. identified endothelin- 1 as an environmental factor to induce the pathological phenotypes, including the cardiomyocyte hypertrophy and intracellular myofibrillar disarray, in HCM patient iPSC cardiomyocytes. They demonstrated that blocking ET-1 signaling by an ETA (endothelin receptor A)-blocker attenuated the abnormal phenotypes, indicating a potential therapeutic target in the endothelin pathway (Tanaka et al. 2014). Recently, Green et al. used HCM model mice to discover that the novel small compound MYK-461 reduces cardiomyocyte contractility by decreasing the adenosine triphosphatase activity of the cardiac myosin heavy chain. The administration of MYK-461 suppressed the development of ventricular hypertrophy and fibrosis in HCM model mice (Green et al. 2016). Following this study, they demonstrated that iPSC cardiomyocytes with a mutation in MYH7 showed HCM phenotypes, including contraction/relaxation abnormality and metabolic abnormality, and that MYH-461 rescued these abnormalities, showing the usefulness of iPSC cardiomyocytes in preclinical studies (Toepfer et al. 2020). MYK-461 (Mavacamten) is now under a phase 2 clinical trial for patients with symptomatic obstructive HCM.

Dilated cardiomyopathy (DCM) is the other major form of cardiomyopathy. DCM heart manifests with ventricular dilatation, thinning walls, and decreased contractile function, resulting in severe heart failure (Schultheiss et al. 2019; Hershberger et al. 2013). Numerous genes causing DCM have been identified, such as TTN, LMNA, MYH7, TNNT2, MYBPC3, PLN, and DES (Reichart et al. 2019; McNally and Mestroni 2017). Sun et al. first reported the DCM model using iPSC cardiomyocytes from patients with TNNT2 (R173W) mutation. They showed that these iPSC cardiomyocytes have abnormal calcium handling, decreased contractility, and a disorganized sarcomere. They also demonstrated that a beta-adrenergic stimulus worsens the disease phenotypes and that beta-blocker treatment or the overexpression of sarcoplasmic reticulum calcium adenosine triphosphatase (SERCA2) improved them (Sun et al. 2012). In a recent report, Dai et al. used iPSC lines with the same TNNT2 (R173W) mutation and revealed that this mutation destabilized the interaction of troponin with other sarcomere proteins, resulting in the impairment of MYH7-mediated, AMPK-dependent sarcomere-cytoskeleton filament interactions. They therefore applied the AMPK activator A-769662 to DCM patient iPSC cardiomyocytes and observed a partial recovery of the sarcomere disorganization and impaired contractility in A-769662-treated DCM iPSC cardiomyocytes in vitro (Dai et al. 2020). In another report, Hinson et al. (2015) generated DCM models with TTN-mutated iPSC cardiomyocytes, finding the cells had sarcomere insufficiency and impaired responses to mechanical and beta-adrenergic stimuli. Karakikes et al. (2015) generated iPSC cardiomyocytes from a patient harboring the phospholamban (PLN) mutation and showed that the mutation induced abnormal calcium handling, electrical instability, and an abnormal cytoplasmic distribution of PLN protein. In addition to those 
studies, there are iPSC-based models for Duchenne muscular dystrophy-related cardiomyopathy (Dick et al. 2013; Lin et al. 2015), Barth syndrome-related cardiomyopathy (Wang et al. 2014b), and DCM related to LMNA, BAG3, and MYH7 mutations (Norton et al. 2011; Yang et al. 2018; Lee et al. 2017, 2019).

Although both HCM and DCM iPSC cardiomyocyte models have provided promising results, including elucidation of the mechanisms underlying these cardiomyopathies, none have recapitulated all the phenotypes, including the disease progression from the early stage to end-stage heart failure in vitro. Additionally, any novel drugs discovered based on these models have not been applied to patients with cardiomyopathies. The reason may be because of the relatively immature phenotype of iPSC cardiomyocytes or the lack of non-myocyte populations that play essential roles for the disease progression. New maturation methods and co-culture platforms containing non-myocytes are required for in vitro cardiomyopathy models to fully recapitulate the phenotypes seen in patients.

\section{Arrhythmogenic cardiomyopathy/arrhythmogenic right ventricular cardiomyopathy}

Arrhythmogenic right ventricular cardiomyopathy (ARVC) is an inherited cardiomyopathy traditionally characterized by the fibro-fatty replacement of cardiomyocytes predominantly in the right ventricle, resulting in arrhythmogenicity and sudden cardiac death in young patients. Several desmosome-related genes causing ARVC have been identified, such as DSG2 (desmoglein-2), PKP2 (plakophilin-2), DSC2 (desmocollin-2), and DSP (desmoplakin) (Corrado et al. 2020; Thiene 2015). A series of clinical studies have revealed that the involvement of the left ventricle varies, and there are cases in which the fibro-fatty replacement was observed both in the right ventricle and left ventricle or dominantly in the left ventricle. Since those studies, the disease has been broadly named arrhythmogenic cardiomyopathy (ACM). Currently, patients with ACM show not only mutations in desmosome-related genes, but also in other genes, including DES (desmin), PLN (phospholamban), LMNA (lamin A/C), and CDH2 (cadherin-2) (Chen et al. 2019). In previous studies using model organisms, it has been reported that second heart field progenitors and cardiac mesenchymal stromal cells could be sources of adipocytes in ACM hearts (Sommariva et al. 2016; Lombardi et al. 2009). Given that the epicardium is known to give rise to cardiac mesenchymal stromal cells in the developing heart, several reports have suggested the contribution of the epicardium to the pathogenesis (Yuan et al. 2021). Matthes et al. reported that PKP2 knockdown in epicardium increased lipid droplets, cell migration, and the proliferation of epicardium-derived cells, suggesting the possibility that epicardium cells could contribute to the pathophysiology of ACM (Matthes et al. 2011). More recently, Dorn et al. demonstrated that abnormal cell-cell contacts due to the mutated PKP2 activated an ectopic fat gene program during cardiomyocyte differentiation, which switches the cell fate to adipocytes, and the adipocytes themselves are derived from cardiac progenitors expressing ISL1 and WT1 (Dorn et al. 2018). Although these results indicate the importance of desmosome genes for cell fate decisions in the heart, no previous studies have clearly answered which cell type is the actual source of the lipid accumulation in ACM heart or why fibro-fatty replacement in the left and right ventricles varies among patients with different mutations. (Sommariva et al. 2017).

Using ACM patient iPSCs, researchers have established in vitro ACM models. Kim et al. established iPSC lines with PKP2 mutations and demonstrated abnormal plakoglobin nuclear translocation without abnormal lipid accumulation under a standard differentiation protocol. They then induced both adult metabolism and pathogenic conditions by culturing the cells in an adipogenic cocktail containing insulin, dexamethasone (Dex), IBMX, PPAR $\gamma$ agonist, and indomethacin, which induced ACM-specific phenotypes, such as lipid accumulation and cell apoptosis, in iPSC cardiomyocytes with PKP2 mutation (Kim et al. 2013). Caspi et al. also reported that combining IBMX, Dex, insulin, and lipid supplementation could worsen the ACM phenotypes in iPSC cardiomyocytes with the same PKP2 mutation (Caspi et al. 2013). Furthermore, Cho et al. showed that in vitro iPSC cardiomyocytes matured when transplanted into neonatal rat hearts in vivo and applied an in vivo maturation method to model ACM using iPSC cardiomyocytes. They observed that the engrafted ACM iPSC cardiomyocytes recapitulated ACM phenotypes, including increased lipid droplets, abnormal intercalated discs, and increased apoptosis, one month following the transplantation, even though the cells did not show any ACM phenotypes in vitro (Cho et al. 2017). All these studies indicate the need to add maturation stimuli, disease-specific pathological stimuli, or in vivo environments to establish more clinically relevant ACM models. These models will further benefit from appropriate differentiation methods for several cell types, including the left and right ventricular cardiomyocytes, and the development of the co-culture platforms to observe cellular interactions precisely to fully understand the mechanisms in ACM heart using iPSC-based disease models.

\section{Modeling drug-induced cardiotoxicity}

Drug-induced cardiotoxicity is a major hurdle for drug discovery. About $30 \%$ of phase 2 clinical trials have failed due to safety issues, including cardiotoxicity, and cardiotoxicity 
is one of the leading causes for drug withdrawals even after new drugs appear in the market (Onakpoya et al. 2016; Arrowsmith and Miller 2013). One of the frequent side effects of these drugs is the blockade of the $\mathrm{I}_{\mathrm{Kr}}$ current, resulting in QT interval prolongation and fatal ventricular arrhythmia, such as Torsade de Pointes (TdP). Traditionally, researchers have used immortal cell lines expressing hERG (KCNH2 encoding the $\mathrm{I}_{\mathrm{Kr}}$ channel) to test if the compounds of interest block the $\mathrm{I}_{\mathrm{Kr}}$ channel and prolong the QT interval. However, these in vitro cell lines are quite distinct from human cardiomyocytes. Although mouse models can be used to test drug-induced cardiotoxicity, they do not fully recapitulate human cases due to the different electrophysiological properties and faster beating rate. As a result, traditional methods for drug testing show low specificity and cannot precisely predict the risk of arrhythmogenicity (Gintant et al. 2016). In addition to the arrhythmogenicity, reducing left ventricular (LV) contractile function is a major side effect of several drugs, such as cancer drugs. For example, anthracyclines as well as tyrosine kinase inhibitors and trastuzumab are known to induce contractile abnormality and heart failure in a series of clinical studies (Chen et al. 2008; Lenneman and Sawyer 2016; Han et al. 2017).

iPSC cardiomyocytes provide an alternative tool to test the cardiotoxicity of drugs in vitro. Navarette et al. tested if human iPSC cardiomyocytes respond to torsadogenic hERG blockers, finding behavior consistent with the reported drug effects in the literature. They showed that torsadogenic hERG blockers, such as sotalol and quinidine, induced early afterdepolarization and ectopic beats in iPSC cardiomyocytes with a significantly higher rate than untreated controls (Navarrete et al. 2013). Kawatou et al. successfully generated an in vitro TdP model using 3D cardiac tissues derived from human iPSCs. Upon treatment with $\mathrm{I}_{\mathrm{Kr}}$ channel blockers, the tissues showed tachyarrhythmia with characteristics of TdP, including a typical polymorphic extracellular field potential and spiral wave re-entry (Kawatou et al. 2017). Kopljar et al. established the motion field imaging-based contraction measurement assay to evaluate the effect of chronic exposure to cardiotoxic drugs, including doxorubicin. They demonstrated that chronic exposure suppressed the contractile motions of iPSC cardiomyocytes and increased the release of cardiac biomarkers, including cTNI and FABP3 (Kopljar et al. 2017). Sharma et al. classified tyrosine kinase inhibitors (TKIs) in terms of cardiotoxicity by measuring alterations in cardiomyocyte viability, contractility, electrophysiology, calcium handling, and signaling. They revealed that TKIs with strong cardiotoxicity effects inhibited vascular endothelial growth factor receptor 2 (VEGFR2) and platelet-derived growth factor receptor (PDGFR), while TKIs with low cardiotoxicity effects did not, and that insulin and IGF1 suppressed the TKI-mediated cardiotoxic effects in iPSC cardiomyocytes (Sharma et al. 2017). All these results indicate that human iPSC cardiomyocytes are useful platforms to test the cardiotoxic effects of drugs and study the mechanisms underlying the drug-induced cardiotoxicity.

At the national level, the Japan iPS Cardiac Safety Assessment (JiCSA) has reported the efficient torsadogenic risk assessment using the multi-electrode array (MEA) and iPSC cardiomyocytes (Ando et al. 2017; Yamazaki et al. 2018). At the international level, several regulatory agencies, including the FDA, European EMA, Health Canada, and Japan NIHS, have started the Comprehensive in Vitro Proarrhythmia Assay (CIPA) initiative to develop new assays that enable a more precise prediction of clinical proarrhythmia risk (Colatsky et al. 2016). The consortium recently reported the result of an international multisite study that characterized the electrophysiological effects of 28 drugs with known clinical torsadogenic risk on 2 commercially available iPSC cardiomyocyte lines across 10 experimental sites, highlighting the importance of standardizing commonly available and easy assays for all researchers and companies (Blinova et al. 2018).

In addition to in vitro cardiotoxicity models, researchers have recently used iPSC cardiomyocytes to identify populations at high risk for drug-induced cardiotoxicity to develop personalized precision medicine. Burridge et al. demonstrated that patient iPSC cardiomyocytes could predict the susceptibility to doxorubicin-induced cardiotoxicity (DIC). They showed that iPSC cardiomyocytes from patients with breast cancer who experienced DIC were more sensitive to doxorubicin toxicity than iPSC cardiomyocytes from patients who did not have DIC (Burridge et al. 2016). Stillitano et al. also demonstrated that iPSC cardiomyocytes could reproduce the susceptibility to develop an arrhythmogenic drug response. They prepared iPSC cardiomyocytes from patients presenting QT prolongation in response to sotalol and those who did not. They confirmed that the response to sotalol in in vitro iPSC cardiomyocytes was strongly correlated to the inter-individual differences observed in vivo (Stillitano et al. 2017). Those results indicate that researchers can predict the patient's response to drugs by analyzing the patient's iPSC cardiomyocytes in vitro. In another report, Matsa et al. provided evidence that iPSC cardiomyocytes can be used in vitro to predict and validate patient-specific drug safety and efficacy. They generated iPSCs from several individuals whose primary heart tissues are also available for analysis and compared their transcriptomes, showing that the NRF2 pathway, which is related to the cellular defense against oxidative stress, varies among patients. They then demonstrated that gene expression patterns related to NRF2-mediated oxidative stress pathways were preserved between iPSC cardiomyocytes and their original primary heart samples. They classified the iPSC cardiomyocytes into low risk, medium risk, and high risk for cardiotoxicity based on the expression of NRF2 pathways and showed that 
several cardiotoxic drugs, such as tacrolimus and rosiglitazone, induced the toxicity only to iPSC cardiomyocytes in the high-risk group and not to iPSC cardiomyocytes in the low risk (Matsa et al. 2016). Taken together, recent advances in cardiotoxicity study using iPSC cardiomyocytes suggest a paradigm shift from traditional animal models or tests using immortal cell lines to more useful and precise drug toxic tests, which may contribute to more efficient drug discovery in the future.

\section{Cardiac cell therapy}

In addition to disease modeling, PSC cardiomyocytes are promising sources for cardiac cell therapy (Laflamme and Murry 2011). For the past decade, researchers have demonstrated the efficacy of the transplantation of PSC cardiomyocytes to damaged hearts. Detailed analyses of the grafted cardiomyocytes have revealed that they couple with the host heart, proliferate and gradually mature during the long-term engraftment, resulting in improved heart function (Funakoshi et al. 2016; Shiba et al. 2012; Chong and Murry 2014). However, there are still several hurdles to overcome for their clinical application in the cell-based therapies. One is the limited engraftment of the injected cardiomyocytes. Only a low percentage of injected cells successfully engraft in the host heart, probably because of cell death or rapid washout from the heart in the acute phase following the injection. Several groups have reported ways to improve survival and engraftment. Laflamme et al. (2007) demonstrated that a pro-survival cocktail, including insulin-like growth factor 1 and cyclosporine, with heat shock treatment prior to the transplantation improved the survival and engraftment of the transplanted PSC cardiomyocytes. Hattori et al. (2010) reported that small PSC cardiomyocyte aggregates, but not single-cell injections, could improve the engraftment because the cells were more likely to be trapped inside the heart due to the relatively larger size of the aggregates. Bargehr et al. (2019) demonstrated that co-transplantation with PSC-derived epicardium could induce the proliferation of the engrafted cardiomyocytes due to several secretion factors derived from the epicardium, resulting in a larger graft size with improved therapeutic effects. Though promising, further investigations to enhance the survival and proliferation of the injected cardiomyocytes for a larger graft size are required. Another issue to overcome is graft-related ventricular arrhythmia. Recently, several groups have successfully established large animal models for cardiac cell therapy using monkeys or pigs with subacute myocardial infarction. They have shown long-term engraftment of the injected cardiomyocytes and therapeutic efficacy along with electrical coupling of the engrafted cardiomyocytes to the host heart. However, fatal ventricular arrhythmia began a few days after the injection and continued for a few weeks (Chong et al. 2014; Shiba et al. 2016). A catheter-based analyses identified that those arrhythmias arose from the micro-re-entry or abnormal impulse generation of the grafted cardiomyocytes (Liu et al. 2018; Romagnuolo et al. 2019). Because these arrhythmias worsen the outcomes of a cell therapy, they must be controlled, presumably by efficient anti-arrhythmia drugs or improving the quality of the transplanted cardiomyocytes with respect to the electrical stability.

\section{Recent progresses on quality of iPSC-derived cells for disease study and treatment}

Although we have shown great achievements by applying iPSC technology to cardiovascular research, further improvements are needed for clinical application. In this section, we discuss recent progress and potential improvements in the quality of the differentiated cells.

\section{Generation of the targeted cardiac subtypes}

As mentioned above, researchers have developed efficient differentiation methods for iPSC cardiomyocytes in vitro following knowledge in developmental biology. Using any of those cardiac differentiation methods, we can generate iPSC cardiomyocytes at high purity. However, the resulting cardiomyocytes represent a mixture of several cardiac subtypes, including ventricular cells, atrial cells, and pacemaker cells.

To generate each cardiac subtype independently, several groups have focused on retinoic acid (RA) signaling for atrial differentiation in the developing heart (Zhang et al. 2011; Devalla et al. 2015). More recently, Lee et al. demonstrated that atrial and ventricular cardiomyocytes are derived from distinct mesoderm populations by manipulating the concentrations of BMP4 and Activin A in the early mesoderm stage, resulting in a clear distinction of the atrial and ventricular fates (Lee et al. 2017). Additionally, several groups have successfully established a differentiation protocol for sinus node pacemaker cardiomyocytes (Birket et al. 2015a; Protze et al. 2017). Thus, researchers can now precisely control cell fate in vitro and generate specific cardiac subtypes, enabling cardiac subtype-specific disease modeling. For example, Laksman et al. established atrial fibrillation (AF) models using PSC-derived atrial cells and demonstrated that flecainide and dofetilide, drugs clinically used for $\mathrm{AF}$ patients, modulate the re-entrant arrhythmogenic activation in differentiated atrial cardiomyocytes (Laksman et al. 2017). A more recent study of theirs reproduced the clinical cardiotoxicity of Ibrutinib, a drug for leukemia, by demonstrating that it has a toxic effect on atrial cardiomyocytes, but not on ventricular cardiomyocytes (Shafaattalab et al. 2019). Additionally, Goldfracht et al. generated 
Fig. 2 Subtype differentiation of iPSCs and platforms to model diseases

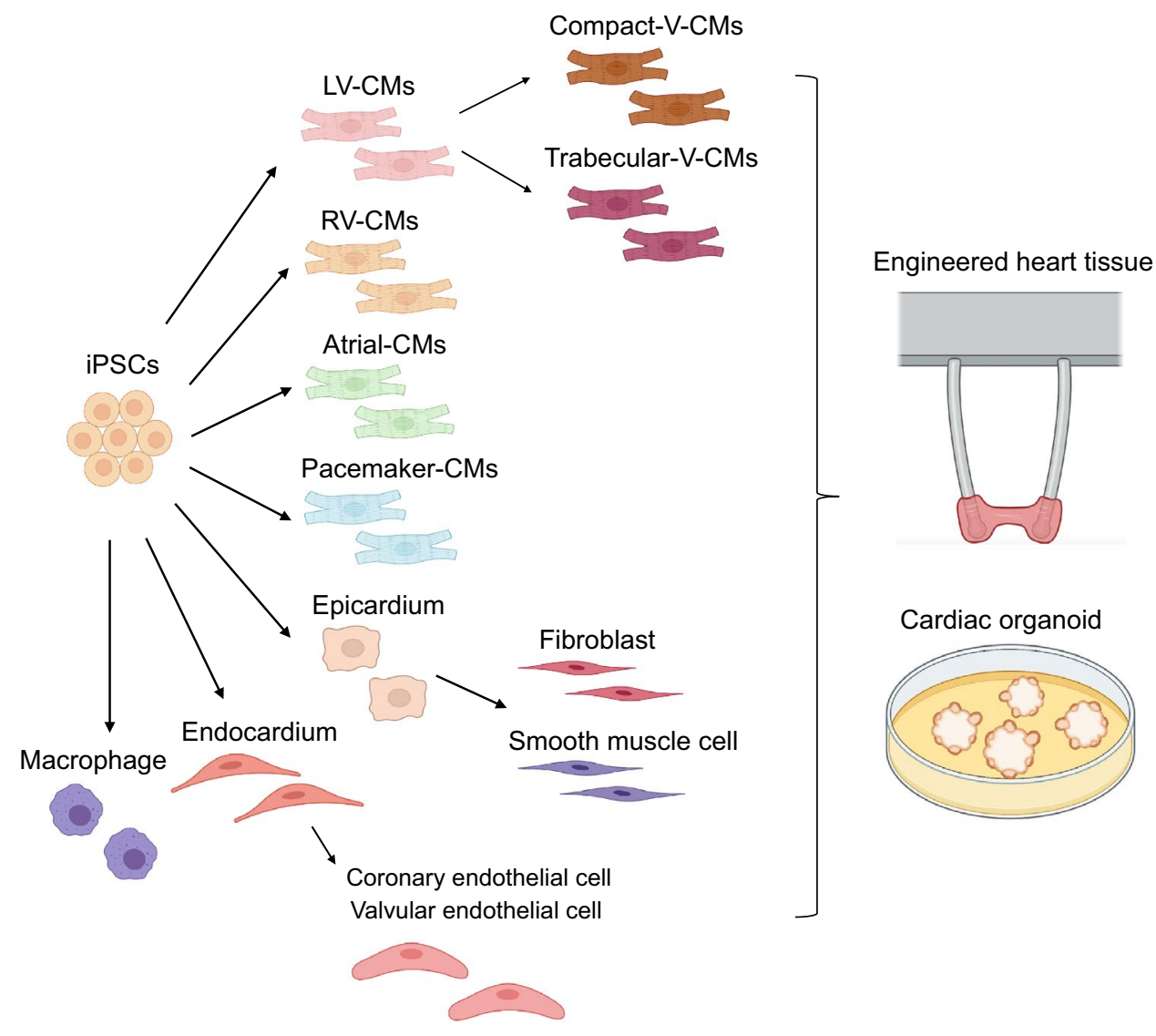

atrial- and ventricular-specific engineered heart tissues and demonstrated that lidocaine, a sodium channel blocker used to treat ventricular arrhythmia, decreased the conduction velocity only in the ventricular tissues and not in the atrial tissues (Goldfracht et al. 2020). Zhao et al. generated heteropolar cardiac tissues containing atrial and ventricular ends and showed their spatially different responses to several drugs (Zhao et al. 2019). Although no previous reports have established models of sinus node-specific diseases, such as sick sinus syndrome, the above results suggest that precise differentiation into each cardiac subtype provides more precise platforms to analyze disease phenotypes and drug responses. Furthermore, in the developing heart, it is well known that there are two distinct subpopulations in the ventricle: trabecular and compact cardiomyocytes. Recent reports demonstrated the successful generation of trabecular and compact ventricular PSC cardiomyocytes by manipulating neuregulin and Wnt signaling, respectively (Mikryukov et al. 2021; Funakoshi et al. 2021). The specified ventricular cardiomyocytes would be helpful to analyze trabeculationand compaction-related diseases, such as LV non-compaction. However, generating right ventricular (RV) and LV cardiomyocytes independently in vitro remains a challenge. LV cardiomyocytes are developed from the first heart field (FHF), while RV cardiomyocytes are from the second heart field (SHF). Andersen et al. demonstrated that differentiated ventricular cells are mixed populations of FHF-derived and SHF-derived cells using a double reporter cell line, HCN4 (FHF marker)-GFP and TBX1 (SHF marker)-RFP. They showed $\mathrm{HCN}^{+}{ }^{+}$cells expressed the FHF markers TBX5 and HAND1, while TBX $1^{+}$cells expressed the SHF markers FGF8, FGF10, and SIX2, and further identified CXCR4 as a potential cell surface marker to isolate SHF progenitors (Andersen et al. 2018). Zhang et al. (2019b) also generated a double reporter cell line, TBX5-clover2 and NKX2.5tagRFP, and showed that the $\mathrm{TBX} 5^{+} / \mathrm{NKX} 2.5^{+}$population has FHF features, while the $\mathrm{TBX} 5^{-} / \mathrm{NKX} 2.5^{+}$population has SHF features. Although these studies give promising results, none have demonstrated the direct differentiation of RV and LV cardiomyocytes that express the global gene expression patterns or functions observed in in vivo hearts. Further investigations are essential to fully understand the mechanisms underlying the generation of LV and RV cardiomyocytes in vitro, which will enable the generation of disease models showing the different phenotypes between the left and right ventricles, such as ARVC (Fig. 2).

The cardiac cell type may have profound implications for cardiac cell therapy, since there is still no understanding what happens if cell types are misplaced in the heart. For example, we have no information on the effects of 
transplanting atrial cells or pacemaker cells into the ventricle or RV cells into the left ventricle. Nor do we know if the contamination of the pacemaker cells can cause graftrelated arrhythmias upon transplantation into the ventricle. Further investigations are required to develop safer and more efficient cardiac cell therapy.

\section{Non-myocyte populations in the heart and ideal platforms to recapitulate their interactions with cardiomyocytes}

In the human heart, there are not only cardiomyocytes but also several non-myocyte populations, including the epicardium, endocardium, fibroblasts, endothelial cells, smooth muscle cells, and inflammatory cells, all of which interact tightly with cardiomyocytes both in normal heart development and in disease conditions. Therefore, researchers are also focusing their efforts on generating non-myocyte populations in vitro. The epicardium is an epithelial cell population that consists of the outer epithelial layer spreading around the heart and is known to be a cell source for cardiac fibroblasts and smooth muscle cells through the epithelial-to-mesenchymal transition (EMT) (Cao and Poss 2018). Several groups have successfully generated PSCderived epicardium by manipulating BMP, Wnt, and RA signaling. They also demonstrated that the differentiated epicardium has the potential to differentiate into fibroblasts and smooth muscle cells by adding known factors to induce EMT, such as fibroblast growth factors (FGFs), transforming growth factor-beta (TGFB), and platelet-derived growth factor (PDGF) (Witty et al. 2014; Iyer et al. 2015). Using the differentiated epicardium and its derivatives, Zhang et al. (2019a) demonstrated that the differentiated cardiac fibroblasts are sensitive to both pro- and anti-fibrosis drugs and that those fibroblasts enabled the analysis of the crosstalk between cardiomyocytes and fibroblasts through BNP/ANPNRP1 pathways in cardiac fibrosis. The endocardium is a specialized endothelial cell population that consists of an inner layer of the heart and is well known as a cell source for coronary endothelial cells, valvular endothelial cells, and valvular interstitial cells (Zhang et al. 2018). Recently, several groups have successfully established differentiation protocols of the endocardium from PSCs by manipulating BMP and FGF signaling (Mikryukov et al. 2021; Neri et al. 2019). Neri et al. demonstrated that the differentiated endocardium undergoes EMT, expresses markers of valve interstitial cells when cultured on mouse atrio-ventricular canal cushions, and recapitulates the features of mitral valve prolapse using iPSCs derived from a patient harboring a mutation in DCHS1, a possible cause for mitral valve prolapse (Neri et al. 2019). These studies indicate that differentiated non-myocytes are useful tools for modeling diseases in which non-myocytes play important roles.
In addition to non-myocyte-specific disease modeling, researchers have established co-culture systems to recapitulate the environment of the in vivo heart more precisely, including tight interactions between cardiomyocytes and non-myocytes. Recently, Giacomelli et al. (2020) generated 3D microtissues with healthy-control iPSC cardiomyocytes and iPSC fibroblasts from patients with PKP2 mutation causing ACM and demonstrated that microtissues containing the mutant fibroblasts showed the same arrhythmic behavior observed in patients with ACM. The study also noted that there was a higher proportion of activated myofibroblasts in the mutated fibroblasts, supporting the notion that epicardial cells are a source of the fibro-fatty substitution seen in ACM heart. In a more recent report, Hofbauer et al. generated PSC-derived self-organized 3D cardiac chamber-like structures, named cardioids, containing cardiomyocytes, endothelial cells, and fibroblasts. Using cardioids with the knockout of HAND1, an essential transcription factor for cardiac chamber morphogenesis, they showed an evident defect in cardiac cavity self-organization, indicating that self-organization and genetic cardiac defects can be modeled in this cardioid platform. They additionally demonstrated that the differentiated epicardium spontaneously differentiated into fibroblasts and smooth muscle cells when co-cultured with cardioids and established a cardiac injury model showing the accumulation of extracellular matrix derived from non-myocytes following cryoinjury (Hofbauer et al. 2021). Yang et al. showed the importance of inflammatory cells for disease modeling. They established an immunocardiac co-culture platform containing PSC cardiomyocytes and PSC macrophages to recapitulate the abnormal inflammatory infiltration of macrophages in the heart with COVID-19 infection. They demonstrated that macrophages induced an increase of reactive oxygen species and apoptosis in cardiomyocytes by secreting inflammatory cytokines following exposure to severe acute respiratory syndrome coronavirus 2 (SARS-CoV-2) (Yang et al. 2021).

The above studies give evidence that non-myocytes play important roles in recapitulating disease conditions and that the co-culture of multiple cell types can be an ideal platform to analyze the mechanism of heart disease. Further progress, such as the development of co-culture platforms containing all necessary cell types, are required to fully recapitulate the complex interactions for each cell type in the human heart in vivo during both normal development and disease conditions (Fig. 2).

\section{Maturation of differentiated cardiomyocytes}

Although we are currently able to generate PSC cardiomyocytes with high efficiency, these cells are typically in an immature state; they display a low level of sarcomere organization, insufficient mitochondrial oxidation capacity, 
and underdeveloped calcium handling, thus resembling fetal cardiomyocytes of the early developmental stage (Karbassi et al. 2020). These immature properties hinder drug screenings or disease modeling of adult-onset heart disease, since the cellular characteristics of fetal-like immature cardiomyocytes are quite distinct from those of adult-like mature cardiomyocytes. As we mentioned above, researchers have used their understanding of early heart development in vivo to establish efficient in vitro PSC differentiation protocols for many cell types in the heart. However, regarding cardiac maturation, there is a lack of knowledge about the in vivo heart in the perinatal, postnatal, and adult stages.

A major change in the maturation status occurs at birth, when proliferative fetal cardiomyocytes switch their phenotypes to a non-proliferative type. One of the most remarkable changes at birth is seen in the blood circulation from the maternal circulation to the systemic circulation, which increases the workload of the newborn heart. Following this observation, electrical stimulation and mechanical stress can promote the maturation of PSC cardiomyocytes (RonaldsonBouchard et al. 2018; Feric and Radisic 2016; Nunes et al. 2013). However, cardiomyocytes in vivo usually switch their phenotype rapidly in the postnatal period. For example, in mice, during the first week after birth, cardiomyocytes lose their proliferative phenotype, undergo mitotic quiescence, and shift to the hypertrophic phase (Masters and Riley 2014; Porrello et al. 2011). These observations suggest key factors in the early postnatal period in addition to changes in the workload to induce the rapid phenotypic switch. In rodent studies, several factors have been identified to induce this phenotypic switch. Puente et al. demonstrated that an oxygen-rich postnatal environment was an upstream event that induced reactive oxygen species (ROS) and oxidative damage, resulting in cell cycle arrest during the first postnatal week in mice (Puente et al. 2014). Cardoso et al. focused on a postnatal shift from anaerobic glycolysis to mitochondrial fatty acid utilization in the heart and demonstrated that the latter regulated cell cycle arrest and the maturation status in cardiomyocytes (Cardoso et al. 2020). Similarly, Nakano et al. revealed that the high blood glucose level suppressed cardiac maturation in the perinatal stage in vivo, further supporting the idea that the energy substrate plays an important role in cardiomyocyte maturation (Nakano et al. 2017). Additionally, Hirose et al. provided evidence that the inactivation of thyroid hormone signaling reduces cardiomyocyte maturation and delays cell cycle arrest in postnatal mice (Hirose et al. 2019). The concentration of several hormones, including thyroid hormone and steroid hormone, are dramatically increased in the perinatal period, resulting in an "hormonal surge", compared to the early fetal periods, suggesting the important roles of these hormones for the phenotypic switch in the postnatal stage (Li et al. 2014; Rog-Zielinska et al. 2014). Given these potential factors in cardiomyocyte maturation, researchers have successfully developed methods to promote the maturation level of PSC cardiomyocytes. Several groups reported that culturing cells with lipid-rich media as well as hormonal stimuli, including T3 and Dex, improved the sarcomere organization, mitochondrial function, and calcium handling in PSC cardiomyocytes (Yang et al. 2014, 2019; Gentillon et al. 2019; Mills et al. 2017; Rog-Zielinska et al. 2015; Parikh et al. 2017). We recently developed an efficient maturation protocol using the combination of T3, Dex, PPARa agonist, and palmitate in low glucose-containing media. The PSC cardiomyocytes treated by this protocol showed structural maturation, withdrawal from the cell cycle, and the ability to utilize exogenous fatty acids efficiently as an energy source, which is one of the representative features of the adult-like metabolism in the heart (Funakoshi et al. 2021). In addition to these factors, Sakamoto et al. demonstrated that ERR signaling plays an essential role in postnatal cardiac maturation in mice (Sakamoto et al. 2020). Coincident with this finding, we recently reported that an ERR $\gamma$ agonist enhanced maturation with T-tube formation in iPSC cardiomyocytes in vitro (Miki et al. 2021). Garbern et al. demonstrated that the inhibition of mTOR signaling, which acts as a nutrient sensor and a cell cycle regulator, by a small compound, Torin 1, enhanced the maturation of iPSC cardiomyocytes via p53-induced quiescence (Garbern et al. 2020). All these results indicate that mimicking the in vivo perinatal period can mature PSC cardiomyocytes in vitro. Using these approaches, several groups have shown the importance of maturation in disease modeling using patient iPSCs. Birket et al. (2015b) used a maturation method that combines T3, Dex, and IGF1 to reveal that mature iPSC cardiomyocytes derived from HCM patients with the MYBPC 3 mutation recapitulated the contraction defect in the patients. Feyen et al. (2020) showed that iPSC cardiomyocytes matured in lipid-rich media recapitulate the contraction deficit in the DCM model or electrophysiological abnormality in the long QT syndrome model, but immature PSC cardiomyocytes do not. Also using lipid-rich media, Knight et al. (2021) demonstrated that mature iPSC cardiomyocytes develop pathological hypertrophy with relaxation defects in response to either a pro-hypertrophic agent or HCM-related gene mutation. In a more recent report, Bliley et al. developed 3D engineered heart tissues that show optimal preload and afterload to promote the maturation level of iPSC cardiomyocytes. They applied these engineered heart tissues to model ACM using iPSCs from patients with a mutation in DSP. They observed representative phenotypes of ACM, including abnormal desmosome distribution and impaired systolic and diastolic function, in the engineered tissues, but not if the cells were cultured in typical 2D or 3D culture systems (Bliley et al. 2021). However, even with these adjustments, the maturation level of PSC cardiomyocytes is still comparable to that in 
Fig. 3 In vitro maturation of iPSC cardiomyocytes by mimicking the postnatal maturation process in vivo

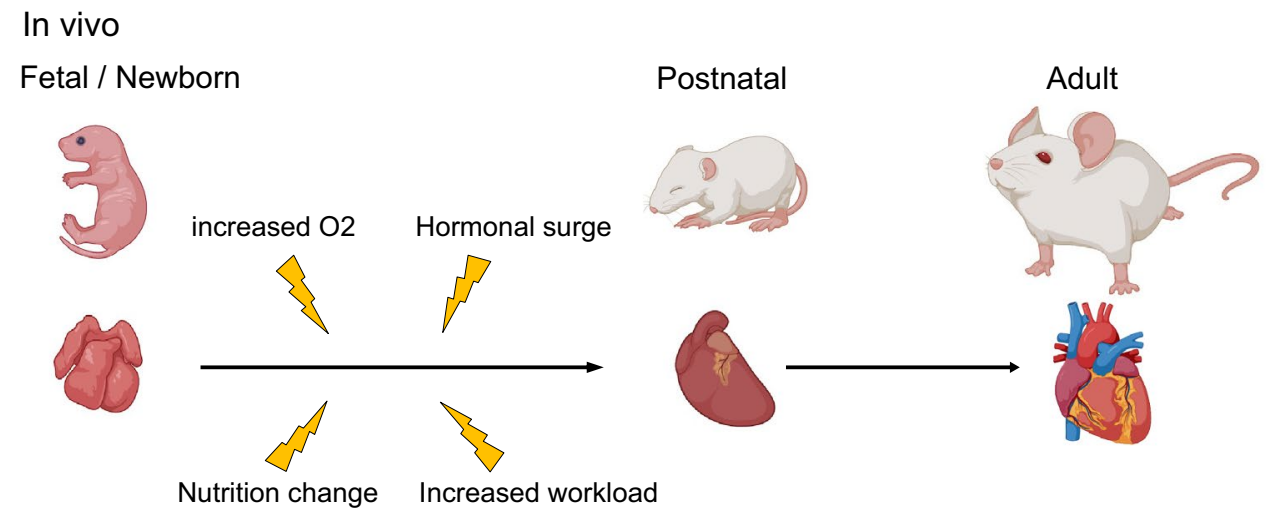

In vitro

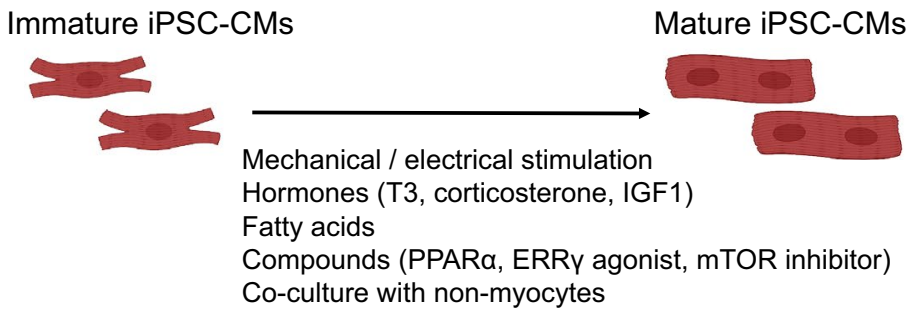

early postnatal heart and not in adult heart. Future research is needed to elucidate the mechanisms underlying the maturation process from the postnatal stage to the adult stage in order to model late adult stage-onset diseases.

Several groups have reported the important roles of nonmyocyte populations in the maturation of cardiomyocytes. Hortells et al. (2020) demonstrated that during the postnatal period in mice, periostin-expressing cardiac fibroblasts contribute to the phenotypic switch from immature cardiomyocytes to mature ones. Wang et al. provided evidence that cardiac fibroblasts also undergo the phenotypic switch from neonatal to adult stage and that this switch regulates the maturation of cardiomyocytes. They also showed that adultlike fibroblasts can enhance the maturation level of neonatal cardiomyocytes (Wang et al. 2020). Coincident with those findings, several groups have established co-culture methods with non-myocytes to enhance the maturation in PSC cardiomyocytes. For example, Giacomelli et al. have generated 3D cardiac microtissues containing iPSC cardiomyocytes, endothelial cells, and epicardium-derived fibroblasts. The 3D microtissues showed improved sarcomere structures, enhanced contractility, and mitochondrial respiration and were electrophysiologically more mature due to the increased level of intracellular cyclic AMP (Giacomelli et al. 2020, 2017). Bargehr et al. (2019) showed PSC-epicardium can enhance the contractility, myofibril structure, and calcium handling of 3D engineered heart tissues when mixed with PSC cardiomyocytes in heart tissues. Presumably, the combination of these co-culture platforms using appropriate non-myocyte populations with compounds or hormones that enhance maturation would further promote the maturation of PSC cardiomyocytes (Fig. 3).

As for cardiac cell therapy, in most previous reports using large animal models, researchers transplanted immature cardiomyocytes and observed graft-related arrhythmia for a few weeks following the transplantation (Shiba et al. 2016; Romagnuolo et al. 2019). Although no previous studies have identified the causes of the graft-related arrhythmia, one possible mechanism is the relatively immature phenotype of the transplanted cardiomyocytes, since they have fetal-like immature electrophysiological properties in vitro. We recently demonstrated that the maturation status in in vitro cardiomyocytes prior to the cell transplantation affected the graft quality, including the expression of CX43, a gap junction protein that increases the electrical stability of the grafted cells, suggesting that the transplantation of mature cardiomyocytes could reduce the occurrence of the graft-related arrhythmias (Funakoshi et al. 2021). Studies transplanting mature cardiomyocytes into large animal may answer this question.

\section{Combination of iPSCs with other emerging technologies}

Recent advances in artificial intelligence and machine learning are remarkable. For example, AlphaGo defeated a world champion of Go, which is considered one of the most complex board games, suggesting that artificial intelligence has already surpassed human performance in some aspects (Silver et al. 2016). In the biology field, machine learning 
has enabled researchers to classify cellular images, build genomic connections, and discover new drugs (Webb 2018). Likewise, in studies related to cardiac disease, researchers have begun to apply these emerging technologies to analyze comprehensive data derived from iPSC cardiomyocytes. Maddah et al. (2020) established an image-based deep learning method to detect and quantify variations in the cellular structures from the immunostaining of PSC cardiomyocytes for drug toxicity. Juhola et al. (2021) applied machine learning to evaluate drug effects in iPSC cardiomyocytes derived from patients carrying mutations causing CPVT and showed that it could predict the drug effect with high accuracy. In addition, a recent report by Theodoris et al. showed the efficiency of combining machine learning and iPSC technology in drug discovery. They established a method to combine gene network analysis and machine learning, resulting in the discovery of new drug candidates that correct dysregulated gene networks in iPSC endothelial cells carrying the NOTCH1 mutation that causes aortic valve (AV) stenosis. The compound identified as the most efficacious rescued not only the iPSC endothelial cells but also patient-derived AV cells and treated AV disease in a mouse model (Theodoris et al. 2021). Current machine learning systems allow us to predict 3D protein structures and protein-protein interactions with remarkably high accuracy and are available to all researchers, which can accelerate the discovery of the new proteins (Jumper et al. 2021; Baek et al. 2021). Collectively, strategies that combine iPSC technology and machine learning could be an effective method to discover candidate therapies in the near future.

\section{Conclusions}

Since iPSCs were first discovered 15 years ago, researchers have applied related technology to cardiovascular research and achieved remarkable progress in many aspects, including disease modeling, platforms for drug discovery and toxicity, and cell-based therapy. Recent progress in methods for cell differentiation, maturation, and the generation of 3D culture platforms with appropriate non-myocyte populations are further accelerating this field. Although no studies have comprehensively recapitulated the environment of the adult human heart using differentiated cells, we assume in vitro models will succeed by combining these methods. Additionally, new technologies for data analysis, such as machine learning, will allow us to apply in vitro models for the discovery of novel therapies effectively. While many challenges remain, a new door has opened for the clinical application of iPSC technologies for cardiovascular diseases.

Acknowledgements We thank Mikako Marx-Mori and Rumi Fujihara for their administrative support and Peter Karagiannis for proofreading the manuscript. This work was supported by JSPS KAKENHI 17H04176 and 21H02912. This work was also supported by the Research Center Network for Realization of Regenerative Medicine, Japan Agency for Medical Research and Development (AMED) (JP19bm0104001, JP19bm0204003, JP19bm0804008, and JP20bm0804022), the Research on Regulatory Science of Pharmaceuticals and Medical Devices, AMED (JP19mk0104117), the Research Project for Practical Applications of Regenerative Medicine, AMED (JP19bk0104095), the Leducq Foundation (18CVD05), and the iPS Cell Research Fund. Figures were generated by BioRender.

\section{Declarations}

Conflict of interest YY received research funding from Takeda Pharmaceutical Company, Ltd.

\section{References}

Andersen P, Tampakakis E, Jimenez DV, Kannan S, Miyamoto M, Shin HK, Saberi A, Murphy S, Sulistio E, Chelko SP, Kwon C (2018) Precardiac organoids form two heart fields via bmp/wnt signaling. Nat Commun 9:3140

Ando H, Yoshinaga T, Yamamoto W, Asakura K, Uda T, Taniguchi T, Ojima A, Shinkyo R, Kikuchi K, Osada T, Hayashi S, Kasai C, Miyamoto N, Tashibu H, Yamazaki D, Sugiyama A, Kanda Y, Sawada K, Sekino Y (2017) A new paradigm for drug-induced torsadogenic risk assessment using human ips cell-derived cardiomyocytes. J Pharmacol Toxicol Methods 84:111-127

Arrowsmith J, Miller P (2013) Trial watch: phase ii and phase iii attrition rates 2011-2012. Nat Rev Drug Discov 12:569

Ashrafian H, Redwood C, Blair E, Watkins H (2003) Hypertrophic cardiomyopathy: a paradigm for myocardial energy depletion. Trends Genet 19:263-268

Baek M, DiMaio F, Anishchenko I, Dauparas J, Ovchinnikov S, Lee GR, Wang J, Cong Q, Kinch LN, Schaeffer RD, Millan C, Park H, Adams C, Glassman CR, DeGiovanni A, Pereira JH, Rodrigues AV, van Dijk AA, Ebrecht AC, Opperman DJ, Sagmeister T, Buhlheller C, Pavkov-Keller T, Rathinaswamy MK, Dalwadi U, Yip CK, Burke JE, Garcia KC, Grishin NV, Adams PD, Read RJ, Baker D (2021) Accurate prediction of protein structures and interactions using a three-track neural network. Science 373:871-876

Bargehr J, Ong LP, Colzani M, Davaapil H, Hofsteen P, Bhandari S, Gambardella L, Le Novere N, Iyer D, Sampaziotis F, Weinberger F, Bertero A, Leonard A, Bernard WG, Martinson A, Figg N, Regnier M, Bennett MR, Murry CE, Sinha S (2019) Epicardial cells derived from human embryonic stem cells augment cardiomyocyte-driven heart regeneration. Nat Biotechnol 37:895-906

Birket MJ, Ribeiro MC, Verkerk AO, Ward D, Leitoguinho AR, den Hartogh SC, Orlova VV, Devalla HD, Schwach V, Bellin M, Passier R, Mummery CL (2015a) Expansion and patterning of cardiovascular progenitors derived from human pluripotent stem cells. Nat Biotechnol 33:970-979

Birket MJ, Ribeiro MC, Kosmidis G, Ward D, Leitoguinho AR, van de Pol V, Dambrot C, Devalla HD, Davis RP, Mastroberardino PG, Atsma DE, Passier R, Mummery CL (2015b) Contractile defect caused by mutation in mybpc 3 revealed under conditions optimized for human psc-cardiomyocyte function. Cell Rep 13:733-745

Bliley JM, Vermeer M, Duffy RM, Batalov I, Kramer D, Tashman JW, Shiwarski DJ, Lee A, Teplenin AS, Volkers L, Coffin B, Hoes MF, Kalmykov A, Palchesko RN, Sun Y, Jongbloed JDH, Bomer N, de Boer RA, Suurmeijer AJH, Pijnappels DA, Bolling 
MC, van der Meer P, Feinberg AW (2021) Dynamic loading of human engineered heart tissue enhances contractile function and drives a desmosome-linked disease phenotype. Sci Transl Med 13:eabd 1817

Blinova K, Dang Q, Millard D, Smith G, Pierson J, Guo L, Brock M, Lu HR, Kraushaar U, Zeng H, Shi H, Zhang X, Sawada K, Osada T, Kanda Y, Sekino Y, Pang L, Feaster TK, Kettenhofen R, Stockbridge N, Strauss DG, Gintant G (2018) International multisite study of human-induced pluripotent stem cell-derived cardiomyocytes for drug proarrhythmic potential assessment. Cell Rep 24:3582-3592

Brandao KO, van den Brink L, Miller DC, Grandela C, van Meer BJ, Mol MPH, de Korte T, Tertoolen LGJ, Mummery CL, Sala L, Verkerk AO, Davis RP (2020) Isogenic sets of hipsc-cms harboring distinct kcnh2 mutations differ functionally and in susceptibility to drug-induced arrhythmias. Stem Cell Rep 15:1127-1139

Burridge PW, Matsa E, Shukla P, Lin ZC, Churko JM, Ebert AD, Lan F, Diecke S, Huber B, Mordwinkin NM, Plews JR, Abilez OJ, Cui B, Gold JD, Wu JC (2014) Chemically defined generation of human cardiomyocytes. Nat Methods 11:855-860

Burridge PW, Li YF, Matsa E, Wu H, Ong SG, Sharma A, Holmstrom A, Chang AC, Coronado MJ, Ebert AD, Knowles JW, Telli ML, Witteles RM, Blau HM, Bernstein D, Altman RB, Wu JC (2016) Human induced pluripotent stem cell-derived cardiomyocytes recapitulate the predilection of breast cancer patients to doxorubicin-induced cardiotoxicity. Nat Med 22:547-556

Cao J, Poss KD (2018) The epicardium as a hub for heart regeneration. Nat Rev Cardiol 15:631-647

Cardoso AC, Lam NT, Savla JJ, Nakada Y, Pereira AHM, Elnwasany A, Menendez-Montes I, Ensley EL, Petric UB, Sharma G, Sherry AD, Malloy CR, Khemtong C, Kinter MT, Tan WLW, AneneNzelu CG, Foo RS, Nguyen NUN, Li S, Ahmed MS, Elhelaly WM, Abdisalaam S, Asaithamby A, Xing C, Kanchwala M, Vale G, Eckert KM, Mitsche MA, McDonald JG, Hill JA, Huang L, Shaul PW, Szweda LI, Sadek HA (2020) Mitochondrial substrate utilization regulates cardiomyocyte cell cycle progression. Nat Metab 2:167-178

Caspi O, Huber I, Gepstein A, Arbel G, Maizels L, Boulos M, Gepstein L (2013) Modeling of arrhythmogenic right ventricular cardiomyopathy with human induced pluripotent stem cells. Circ Cardiovasc Genet 6:557-568

Chen MH, Kerkela R, Force T (2008) Mechanisms of cardiac dysfunction associated with tyrosine kinase inhibitor cancer therapeutics. Circulation 118:84-95

Chen L, Song J, Chen X, Chen K, Ren J, Zhang N, Rao M, Hu Z, Zhang Y, Gu M, Zhao H, Tang H, Yang Z, Hu S (2019) A novel genotype-based clinicopathology classification of arrhythmogenic cardiomyopathy provides novel insights into disease progression. Eur Heart J 40:1690-1703

Cho GS, Lee DI, Tampakakis E, Murphy S, Andersen P, Uosaki H, Chelko S, Chakir K, Hong I, Seo K, Chen HV, Chen X, Basso C, Houser SR, Tomaselli GF, O'Rourke B, Judge DP, Kass DA, Kwon C (2017) Neonatal transplantation confers maturation of psc-derived cardiomyocytes conducive to modeling cardiomyopathy. Cell Rep 18:571-582

Chong JJ, Murry CE (2014) Cardiac regeneration using pluripotent stem cells-progression to large animal models. Stem Cell Res 13:654-665

Chong JJ, Yang X, Don CW, Minami E, Liu YW, Weyers JJ, Mahoney WM, Van Biber B, Cook SM, Palpant NJ, Gantz JA, Fugate JA, Muskheli V, Gough GM, Vogel KW, Astley CA, Hotchkiss CE, Baldessari A, Pabon L, Reinecke H, Gill EA, Nelson V, Kiem HP, Laflamme MA, Murry CE (2014) Human embryonic-stemcell-derived cardiomyocytes regenerate non-human primate hearts. Nature 510:273-277
Cohn R, Thakar K, Lowe A, Ladha FA, Pettinato AM, Romano R, Meredith E, Chen YS, Atamanuk K, Huey BD, Hinson JT (2019) A contraction stress model of hypertrophic cardiomyopathy due to sarcomere mutations. Stem Cell Rep 12:71-83

Colatsky T, Fermini B, Gintant G, Pierson JB, Sager P, Sekino Y, Strauss DG, Stockbridge N (2016) The comprehensive in vitro proarrhythmia assay (cipa) initiative - update on progress. J Pharmacol Toxicol Methods 81:15-20

Corrado D, van Tintelen PJ, McKenna WJ, Hauer RNW, Anastastakis A, Asimaki A, Basso C, Bauce B, Brunckhorst C, BucciarelliDucci C, Duru F, Elliott P, Hamilton RM, Haugaa KH, James CA, Judge D, Link MS, Marchlinski FE, Mazzanti A, Mestroni L, Pantazis A, Pelliccia A, Marra MP, Pilichou K, Platonov PGA, Protonotarios A, Rampazzo A, Saffitz JE, Saguner AM, Schmied C, Sharma S, Tandri H, Te Riele A, Thiene G, Tsatsopoulou A, Zareba W, Zorzi A, Wichter T, Marcus FI, Calkins H, International E (2020) Arrhythmogenic right ventricular cardiomyopathy: evaluation of the current diagnostic criteria and differential diagnosis. Eur Heart J 41:1414-1429

Dai Y, Amenov A, Ignatyeva N, Koschinski A, Xu H, Soong PL, Tiburcy M, Linke WA, Zaccolo M, Hasenfuss G, Zimmermann WH, Ebert A (2020) Troponin destabilization impairs sarcomerecytoskeleton interactions in ipsc-derived cardiomyocytes from dilated cardiomyopathy patients. Sci Rep 10:209

Devalla HD, Schwach V, Ford JW, Milnes JT, El-Haou S, Jackson C, Gkatzis K, Elliott DA, de Sousa Lopes SMC, Mummery CL, Verkerk AO, Passier R (2015) Atrial-like cardiomyocytes from human pluripotent stem cells are a robust preclinical model for assessing atrial-selective pharmacology. EMBO Mol Med 7:394-410

Dick E, Kalra S, Anderson D, George V, Ritso M, Laval SH, Barresi R, Aartsma-Rus A, Lochmuller H, Denning C (2013) Exon skipping and gene transfer restore dystrophin expression in human induced pluripotent stem cells-cardiomyocytes harboring dmd mutations. Stem Cells Dev 22:2714-2724

Dorn T, Kornherr J, Parrotta EI, Zawada D, Ayetey H, Santamaria G, Iop L, Mastantuono E, Sinnecker D, Goedel A, Dirschinger RJ, My I, Laue S, Bozoglu T, Baarlink C, Ziegler T, Graf E, Hinkel R, Cuda G, Kaab S, Grace AA, Grosse R, Kupatt C, Meitinger T, Smith AG, Laugwitz KL, Moretti A (2018) Interplay of cellcell contacts and rhoa/mrtf-a signaling regulates cardiomyocyte identity. EMBO J 37:e98133

Dubois NC, Craft AM, Sharma P, Elliott DA, Stanley EG, Elefanty AG, Gramolini A, Keller G (2011) Sirpa is a specific cell-surface marker for isolating cardiomyocytes derived from human pluripotent stem cells. Nat Biotechnol 29:1011-1018

Fan C, Zhang E, Joshi J, Yang J, Zhang J, Zhu W (2020) Utilization of human induced pluripotent stem cells for cardiac repair. Front Cell Dev Biol 8:36

Feric NT, Radisic M (2016) Maturing human pluripotent stem cellderived cardiomyocytes in human engineered cardiac tissues. Adv Drug Deliv Rev 96:110-134

Feyen DAM, McKeithan WL, Bruyneel AAN, Spiering S, Hormann L, Ulmer B, Zhang H, Briganti F, Schweizer M, Hegyi B, Liao Z, Polonen RP, Ginsburg KS, Lam CK, Serrano R, Wahlquist C, Kreymerman A, Vu M, Amatya PL, Behrens CS, Ranjbarvaziri S, Maas RGC, Greenhaw M, Bernstein D, Wu JC, Bers DM, Eschenhagen T, Metallo CM, Mercola M (2020) Metabolic maturation media improve physiological function of human ipscderived cardiomyocytes. Cell Rep 32:107925

Funakoshi S, Miki K, Takaki T, Okubo C, Hatani T, Chonabayashi K, Nishikawa M, Takei I, Oishi A, Narita M, Hoshijima M, Kimura T, Yamanaka S, Yoshida Y (2016) Enhanced engraftment, proliferation, and therapeutic potential in heart using optimized human ipsc-derived cardiomyocytes. Sci Rep 6:19111 
Funakoshi S, Fernandes I, Mastikhina O, Wilkinson D, Tran T, Dhahri W, Mazine A, Yang D, Burnett B, Lee J, Protze S, Bader GD, Nunes SS, Laflamme M, Keller G (2021) Generation of mature compact ventricular cardiomyocytes from human pluripotent stem cells. Nat Commun 12:3155

Gao L, Gregorich ZR, Zhu W, Mattapally S, Oduk Y, Lou X, Kannappan R, Borovjagin AV, Walcott GP, Pollard AE, Fast VG, Hu X, Lloyd SG, Ge Y, Zhang J (2018) Large cardiac muscle patches engineered from human induced-pluripotent stem cell-derived cardiac cells improve recovery from myocardial infarction in swine. Circulation 137:1712-1730

Garbern JC, Helman A, Sereda R, Sarikhani M, Ahmed A, Escalante GO, Ogurlu R, Kim SL, Zimmerman JF, Cho A, MacQueen L, Bezzerides VJ, Parker KK, Melton DA, Lee RT (2020) Inhibition of mtor signaling enhances maturation of cardiomyocytes derived from human-induced pluripotent stem cells via p53induced quiescence. Circulation 141:285-300

Gentillon C, Li D, Duan M, Yu WM, Preininger MK, Jha R, Rampoldi A, Saraf A, Gibson GC, Qu CK, Brown LA, Xu C (2019) Targeting hif-1alpha in combination with pparalpha activation and postnatal factors promotes the metabolic maturation of human induced pluripotent stem cell-derived cardiomyocytes. J Mol Cell Cardiol 132:120-135

Giacomelli E, Bellin M, Sala L, van Meer BJ, Tertoolen LG, Orlova VV, Mummery CL (2017) Three-dimensional cardiac microtissues composed of cardiomyocytes and endothelial cells codifferentiated from human pluripotent stem cells. Development 144:1008-1017

Giacomelli E, Meraviglia V, Campostrini G, Cochrane A, Cao X, van Helden RWJ, Krotenberg Garcia A, Mircea M, Kostidis S, Davis RP, van Meer BJ, Jost CR, Koster AJ, Mei H, Miguez DG, Mulder AA, Ledesma-Terron M, Pompilio G, Sala L, Salvatori DCF, Slieker RC, Sommariva E, de Vries AAF, Giera M, Semrau S, Tertoolen LGJ, Orlova VV, Bellin M, Mummery CL (2020) Human-ipsc-derived cardiac stromal cells enhance maturation in $3 \mathrm{~d}$ cardiac microtissues and reveal non-cardiomyocyte contributions to heart disease. Cell Stem Cell 26:862-879 e811

Gintant G, Sager PT, Stockbridge N (2016) Evolution of strategies to improve preclinical cardiac safety testing. Nat Rev Drug Discov 15:457-471

Goldfracht I, Protze S, Shiti A, Setter N, Gruber A, Shaheen N, Nartiss Y, Keller G, Gepstein L (2020) Generating ring-shaped engineered heart tissues from ventricular and atrial human pluripotent stem cell-derived cardiomyocytes. Nat Commun 11:75

Green EM, Wakimoto H, Anderson RL, Evanchik MJ, Gorham JM, Harrison BC, Henze M, Kawas R, Oslob JD, Rodriguez HM, Song Y, Wan W, Leinwand LA, Spudich JA, McDowell RS, Seidman JG, Seidman CE (2016) A small-molecule inhibitor of sarcomere contractility suppresses hypertrophic cardiomyopathy in mice. Science 351:617-621

Han X, Zhou Y, Liu W (2017) Precision cardio-oncology: understanding the cardiotoxicity of cancer therapy. NPJ Precis Oncol 1:31

Hattori F, Chen H, Yamashita H, Tohyama S, Satoh YS, Yuasa S, Li W, Yamakawa H, Tanaka T, Onitsuka T, Shimoji K, Ohno Y, Egashira T, Kaneda R, Murata M, Hidaka K, Morisaki T, Sasaki E, Suzuki T, Sano M, Makino S, Oikawa S, Fukuda K (2010) Nongenetic method for purifying stem cell-derived cardiomyocytes. Nat Methods 7:61-66

Hershberger RE, Hedges DJ, Morales A (2013) Dilated cardiomyopathy: the complexity of a diverse genetic architecture. Nat Rev Cardiol 10:531-547

Hinson JT, Chopra A, Nafissi N, Polacheck WJ, Benson CC, Swist S, Gorham J, Yang L, Schafer S, Sheng CC, Haghighi A, Homsy J, Hubner N, Church G, Cook SA, Linke WA, Chen CS, Seidman JG, Seidman CE (2015) Heart disease. Titin mutations in ips cells define sarcomere insufficiency as a cause of dilated cardiomyopathy. Science 349:982-986

Hirose K, Payumo AY, Cutie S, Hoang A, Zhang H, Guyot R, Lunn D, Bigley RB, Yu H, Wang J, Smith M, Gillett E, Muroy SE, Schmid T, Wilson E, Field KA, Reeder DM, Maden M, Yartsev MM, Wolfgang MJ, Grutzner F, Scanlan TS, Szweda LI, Buffenstein R, Hu G, Flamant F, Olgin JE, Huang GN (2019) Evidence for hormonal control of heart regenerative capacity during endothermy acquisition. Science 364:184-188

Hofbauer P, Jahnel SM, Papai N, Giesshammer M, Deyett A, Schmidt C, Penc M, Tavernini K, Grdseloff N, Meledeth C, Ginistrelli LC, Ctortecka C, Salic S, Novatchkova M, Mendjan S (2021) Cardioids reveal self-organizing principles of human cardiogenesis. Cell 184:3299-3317 e3222

Hortells L, Valiente-Alandi I, Thomas ZM, Agnew EJ, Schnell DJ, York AJ, Vagnozzi RJ, Meyer EC, Molkentin JD, Yutzey KE (2020) A specialized population of periostin-expressing cardiac fibroblasts contributes to postnatal cardiomyocyte maturation and innervation. Proc Natl Acad Sci USA 117:21469-21479

Huangfu D, Maehr R, Guo W, Eijkelenboom A, Snitow M, Chen AE, Melton DA (2008) Induction of pluripotent stem cells by defined factors is greatly improved by small-molecule compounds. Nat Biotechnol 26:795-797

Itzhaki I, Maizels L, Huber I, Zwi-Dantsis L, Caspi O, Winterstern A, Feldman O, Gepstein A, Arbel G, Hammerman H, Boulos M, Gepstein L (2011) Modelling the long qt syndrome with induced pluripotent stem cells. Nature 471:225-229

Iyer D, Gambardella L, Bernard WG, Serrano F, Mascetti VL, Pedersen RA, Talasila A, Sinha S (2015) Robust derivation of epicardium and its differentiated smooth muscle cell progeny from human pluripotent stem cells. Development 142:1528-1541

Juhola M, Penttinen K, Joutsijoki H, Aalto-Setala K (2021) Analysis of drug effects on ipsc cardiomyocytes with machine learning. Ann Biomed Eng 49:129-138

Jumper J, Evans R, Pritzel A, Green T, Figurnov M, Ronneberger O, Tunyasuvunakool K, Bates R, Zidek A, Potapenko A, Bridgland A, Meyer C, Kohl SAA, Ballard AJ, Cowie A, Romera-Paredes B, Nikolov S, Jain R, Adler J, Back T, Petersen S, Reiman D, Clancy E, Zielinski M, Steinegger M, Pacholska M, Berghammer T, Bodenstein S, Silver D, Vinyals O, Senior AW, Kavukcuoglu K, Kohli P, Hassabis D (2021) Highly accurate protein structure prediction with alphafold. Nature 596:583-589

Jung CB, Moretti A, Mederos y Schnitzler M, Iop L, Storch U, Bellin M, Dorn T, Ruppenthal S, Pfeiffer S, Goedel A, Dirschinger RJ, Seyfarth M, Lam JT, Sinnecker D, Gudermann T, Lipp P, Laugwitz KL (2012) Dantrolene rescues arrhythmogenic ryr2 defect in a patient-specific stem cell model of catecholaminergic polymorphic ventricular tachycardia. EMBO Mol Med 4:180-191

Kaji K, Norrby K, Paca A, Mileikovsky M, Mohseni P, Woltjen K (2009) Virus-free induction of pluripotency and subsequent excision of reprogramming factors. Nature 458:771-775

Karakikes I, Stillitano F, Nonnenmacher M, Tzimas C, Sanoudou D, Termglinchan V, Kong CW, Rushing S, Hansen J, Ceholski D, Kolokathis F, Kremastinos D, Katoulis A, Ren L, Cohen N, Gho J, Tsiapras D, Vink A, Wu JC, Asselbergs FW, Li RA, Hulot JS, Kranias EG, Hajjar RJ (2015) Correction of human phospholamban r14del mutation associated with cardiomyopathy using targeted nucleases and combination therapy. Nat Commun 6:6955

Karbassi E, Fenix A, Marchiano S, Muraoka N, Nakamura K, Yang X, Murry CE (2020) Cardiomyocyte maturation: advances in knowledge and implications for regenerative medicine. Nat Rev Cardiol 17:341-359

Kattman SJ, Witty AD, Gagliardi M, Dubois NC, Niapour M, Hotta A, Ellis J, Keller G (2011) Stage-specific optimization of activin/ nodal and bmp signaling promotes cardiac differentiation of 
mouse and human pluripotent stem cell lines. Cell Stem Cell $8: 228-240$

Kawamura M, Miyagawa S, Fukushima S, Saito A, Miki K, Funakoshi S, Yoshida Y, Yamanaka S, Shimizu T, Okano T, Daimon T, Toda K, Sawa Y (2017) Enhanced therapeutic effects of human ips cell derived-cardiomyocyte by combined cell-sheets with omental flap technique in porcine ischemic cardiomyopathy model. Sci Rep 7:8824

Kawatou M, Masumoto H, Fukushima H, Morinaga G, Sakata R, Ashihara T, Yamashita JK (2017) Modelling torsade de pointes arrhythmias in vitro in $3 \mathrm{~d}$ human ips cell-engineered heart tissue. Nat Commun 8:1078

Kim C, Wong J, Wen J, Wang S, Wang C, Spiering S, Kan NG, Forcales S, Puri PL, Leone TC, Marine JE, Calkins H, Kelly DP, Judge DP, Chen HS (2013) Studying arrhythmogenic right ventricular dysplasia with patient-specific ipscs. Nature 494:105-110

Knight WE, Cao Y, Lin YH, Chi C, Bai B, Sparagna GC, Zhao Y, Du Y, Londono P, Reisz JA, Brown BC, Taylor MRG, Ambardekar AV, Cleveland JC Jr, McKinsey TA, Jeong MY, Walker LA, Woulfe KC, D'Alessandro A, Chatfield KC, Xu H, Bristow MR, Buttrick PM, Song K (2021) Maturation of pluripotent stem cellderived cardiomyocytes enables modeling of human hypertrophic cardiomyopathy. Stem Cell Rep 16:519-533

Kopljar I, De Bondt A, Vinken P, Teisman A, Damiano B, Goeminne N, Van den Wyngaert I, Gallacher DJ, Lu HR (2017) Chronic drug-induced effects on contractile motion properties and cardiac biomarkers in human induced pluripotent stem cell-derived cardiomyocytes. Br J Pharmacol 174:3766-3779

Laflamme MA, Murry CE (2011) Heart regeneration. Nature 473:326-335

Laflamme MA, Chen KY, Naumova AV, Muskheli V, Fugate JA, Dupras SK, Reinecke H, Xu C, Hassanipour M, Police S, O'Sullivan C, Collins L, Chen Y, Minami E, Gill EA, Ueno S, Yuan C, Gold J, Murry CE (2007) Cardiomyocytes derived from human embryonic stem cells in pro-survival factors enhance function of infarcted rat hearts. Nat Biotechnol 25:1015-1024

Laksman Z, Wauchop M, Lin E, Protze S, Lee J, Yang W, Izaddoustdar F, Shafaattalab S, Gepstein L, Tibbits GF, Keller G, Backx PH (2017) Modeling atrial fibrillation using human embryonic stem cell-derived atrial tissue. Sci Rep 7:5268

Lan F, Lee AS, Liang P, Sanchez-Freire V, Nguyen PK, Wang L, Han L, Yen M, Wang Y, Sun N, Abilez OJ, Hu S, Ebert AD, Navarrete EG, Simmons CS, Wheeler M, Pruitt B, Lewis R, Yamaguchi Y, Ashley EA, Bers DM, Robbins RC, Longaker MT, Wu JC (2013) Abnormal calcium handling properties underlie familial hypertrophic cardiomyopathy pathology in patient-specific induced pluripotent stem cells. Cell Stem Cell 12:101-113

Lee JH, Protze SI, Laksman Z, Backx PH, Keller GM (2017) Human pluripotent stem cell-derived atrial and ventricular cardiomyocytes develop from distinct mesoderm populations. Cell Stem Cell 21:179-194 e174

Lee YK, Lau YM, Cai ZJ, Lai WH, Wong LY, Tse HF, Ng KM, Siu CW (2017) Modeling treatment response for lamin a/c related dilated cardiomyopathy in human induced pluripotent stem cells. J Am Heart Assoc 6:e005677

Lee J, Termglinchan V, Diecke S, Itzhaki I, Lam CK, Garg P, Lau E, Greenhaw M, Seeger T, Wu H, Zhang JZ, Chen X, Gil IP, Ameen M, Sallam K, Rhee JW, Churko JM, Chaudhary R, Chour T, Wang PJ, Snyder MP, Chang HY, Karakikes I, Wu JC (2019) Activation of pdgf pathway links lmna mutation to dilated cardiomyopathy. Nature 572:335-340

Lenneman CG, Sawyer DB (2016) Cardio-oncology: an update on cardiotoxicity of cancer-related treatment. Circ Res 118:1008-1020
Li M, Iismaa SE, Naqvi N, Nicks A, Husain A, Graham RM (2014) Thyroid hormone action in postnatal heart development. Stem Cell Res 13:582-591

Li W, Stauske M, Luo X, Wagner S, Vollrath M, Mehnert CS, Schubert M, Cyganek L, Chen S, Hasheminasab SM, Wulf G, ElArmouche A, Maier LS, Hasenfuss G, Guan K (2020) Disease phenotypes and mechanisms of ipsc-derived cardiomyocytes from Brugada syndrome patients with a loss-of-function scn5a mutation. Front Cell Dev Biol 8:592893

Lian X, Hsiao C, Wilson G, Zhu K, Hazeltine LB, Azarin SM, Raval KK, Zhang J, Kamp TJ, Palecek SP (2012) Robust cardiomyocyte differentiation from human pluripotent stem cells via temporal modulation of canonical wnt signaling. Proc Natl Acad Sci USA 109:E1848-1857

Liang P, Sallam K, Wu H, Li Y, Itzhaki I, Garg P, Zhang Y, Vermglinchan V, Lan F, Gu M, Gong T, Zhuge Y, He C, Ebert AD, Sanchez-Freire V, Churko J, Hu S, Sharma A, Lam CK, Scheinman MM, Bers DM, Wu JC (2016) Patient-specific and genomeedited induced pluripotent stem cell-derived cardiomyocytes elucidate single-cell phenotype of brugada syndrome. J Am Coll Cardiol 68:2086-2096

Lin B, Li Y, Han L, Kaplan AD, Ao Y, Kalra S, Bett GC, Rasmusson RL, Denning C, Yang L (2015) Modeling and study of the mechanism of dilated cardiomyopathy using induced pluripotent stem cells derived from individuals with duchenne muscular dystrophy. Dis Model Mech 8:457-466

Liu YW, Chen B, Yang X, Fugate JA, Kalucki FA, Futakuchi-Tsuchida A, Couture L, Vogel KW, Astley CA, Baldessari A, Ogle J, Don CW, Steinberg ZL, Seslar SP, Tuck SA, Tsuchida H, Naumova AV, Dupras SK, Lyu MS, Lee J, Hailey DW, Reinecke H, Pabon L, Fryer BH, MacLellan WR, Thies RS, Murry CE (2018) Human embryonic stem cell-derived cardiomyocytes restore function in infarcted hearts of non-human primates. Nat Biotechnol 36:597-605

Lombardi R, Dong J, Rodriguez G, Bell A, Leung TK, Schwartz RJ, Willerson JT, Brugada R, Marian AJ (2009) Genetic fate mapping identifies second heart field progenitor cells as a source of adipocytes in arrhythmogenic right ventricular cardiomyopathy. Circ Res 104:1076-1084

Ma D, Wei H, Lu J, Huang D, Liu Z, Loh LJ, Islam O, Liew R, Shim W, Cook SA (2015) Characterization of a novel kcnq1 mutation for type 1 long qt syndrome and assessment of the therapeutic potential of a novel iks activator using patient-specific induced pluripotent stem cell-derived cardiomyocytes. Stem Cell Res Ther 6:39

Maddah M, Mandegar MA, Dame K, Grafton F, Loewke K, Ribeiro AJS (2020) Quantifying drug-induced structural toxicity in hepatocytes and cardiomyocytes derived from hipscs using a deep learning method. J Pharmacol Toxicol Methods 105:106895

Marian AJ, Braunwald E (2017) Hypertrophic cardiomyopathy: genetics, pathogenesis, clinical manifestations, diagnosis, and therapy. Circ Res 121:749-770

Maron BJ (2018) Clinical course and management of hypertrophic cardiomyopathy. N Engl J Med 379:655-668

Masters M, Riley PR (2014) The epicardium signals the way towards heart regeneration. Stem Cell Res 13:683-692

Matsa E, Burridge PW, Yu KH, Ahrens JH, Termglinchan V, Wu H, Liu C, Shukla P, Sayed N, Churko JM, Shao N, Woo NA, Chao AS, Gold JD, Karakikes I, Snyder MP, Wu JC (2016) Transcriptome profiling of patient-specific human ipsc-cardiomyocytes predicts individual drug safety and efficacy responses in vitro. Cell Stem Cell 19:311-325

Matthes SA, Taffet S, Delmar M (2011) Plakophilin-2 and the migration, differentiation and transformation of cells derived from the epicardium of neonatal rat hearts. Cell Commun Adhes 18:73-84 
McNally EM, Mestroni L (2017) Dilated cardiomyopathy: genetic determinants and mechanisms. Circ Res 121:731-748

Mehta A, Ramachandra CJA, Singh P, Chitre A, Lua CH, Mura M, Crotti L, Wong P, Schwartz PJ, Gnecchi M, Shim W (2018) Identification of a targeted and testable antiarrhythmic therapy for long-qt syndrome type 2 using a patient-specific cellular model. Eur Heart J 39:1446-1455

Miki K, Endo K, Takahashi S, Funakoshi S, Takei I, Katayama S, Toyoda T, Kotaka M, Takaki T, Umeda M, Okubo C, Nishikawa M, Oishi A, Narita M, Miyashita I, Asano K, Hayashi K, Osafune K, Yamanaka S, Saito H, Yoshida Y (2015) Efficient detection and purification of cell populations using synthetic microrna switches. Cell Stem Cell 16:699-711

Miki K, Deguchi K, Nakanishi-Koakutsu M, Lucena-Cacace A, Kondo S, Fujiwara Y, Hatani T, Sasaki M, Naka Y, Okubo C, Narita M, Takei I, Napier SC, Sugo T, Imaichi S, Monjo T, Ando T, Tamura N, Imahashi K, Nishimoto T, Yoshida Y (2021) Errgamma enhances cardiac maturation with t-tubule formation in human ipsc-derived cardiomyocytes. Nat Commun 12:3596

Mikryukov AA, Mazine A, Wei B, Yang D, Miao Y, Gu M, Keller GM (2021) Bmp10 signaling promotes the development of endocardial cells from human pluripotent stem cell-derived cardiovascular progenitors. Cell Stem Cell 28:96-111 e117

Mills RJ, Titmarsh DM, Koenig X, Parker BL, Ryall JG, Quaife-Ryan GA, Voges HK, Hodson MP, Ferguson C, Drowley L, Plowright AT, Needham EJ, Wang QD, Gregorevic P, Xin M, Thomas WG, Parton RG, Nielsen LK, Launikonis BS, James DE, Elliott DA, Porrello ER, Hudson JE (2017) Functional screening in human cardiac organoids reveals a metabolic mechanism for cardiomyocyte cell cycle arrest. Proc Natl Acad Sci USA 114:E8372-E8381

Moretti A, Bellin M, Welling A, Jung CB, Lam JT, Bott-Flugel L, Dorn T, Goedel A, Hohnke C, Hofmann F, Seyfarth M, Sinnecker D, Schomig A, Laugwitz KL (2010) Patient-specific induced pluripotent stem-cell models for long-qt syndrome. N Engl J Med 363:1397-1409

Musunuru K (2013) Genome editing of human pluripotent stem cells to generate human cellular disease models. Dis Model Mech 6:896-904

Nakano H, Minami I, Braas D, Pappoe H, Wu X, Sagadevan A, Vergnes L, Fu K, Morselli M, Dunham C, Ding X, Stieg AZ, Gimzewski JK, Pellegrini M, Clark PM, Reue K, Lusis AJ, Ribalet B, Kurdistani SK, Christofk H, Nakatsuji N, Nakano A (2017) Glucose inhibits cardiac muscle maturation through nucleotide biosynthesis. Elife 6:e29330

Navarrete EG, Liang P, Lan F, Sanchez-Freire V, Simmons C, Gong T, Sharma A, Burridge PW, Patlolla B, Lee AS, Wu H, Beygui RE, Wu SM, Robbins RC, Bers DM, Wu JC (2013) Screening druginduced arrhythmia [corrected] using human induced pluripotent stem cell-derived cardiomyocytes and low-impedance microelectrode arrays. Circulation 128:S3-13

Nerbonne JM (2004) Studying cardiac arrhythmias in the mouse-a reasonable model for probing mechanisms? Trends Cardiovasc Med 14:83-93

Neri T, Hiriart E, van Vliet PP, Faure E, Norris RA, Farhat B, Jagla B, Lefrancois J, Sugi Y, Moore-Morris T, Zaffran S, Faustino RS, Zambon AC, Desvignes JP, Salgado D, Levine RA, de la Pompa JL, Terzic A, Evans SM, Markwald R, Puceat M (2019) Human pre-valvular endocardial cells derived from pluripotent stem cells recapitulate cardiac pathophysiological valvulogenesis. Nat Commun 10:1929

Norton N, Li D, Rieder MJ, Siegfried JD, Rampersaud E, Zuchner S, Mangos S, Gonzalez-Quintana J, Wang L, McGee S, Reiser J, Martin E, Nickerson DA, Hershberger RE (2011) Genome-wide studies of copy number variation and exome sequencing identify rare variants in bag3 as a cause of dilated cardiomyopathy. Am J Hum Genet 88:273-282
Nunes SS, Miklas JW, Liu J, Aschar-Sobbi R, Xiao Y, Zhang B, Jiang J, Masse S, Gagliardi M, Hsieh A, Thavandiran N, Laflamme MA, Nanthakumar K, Gross GJ, Backx PH, Keller G, Radisic M (2013) Biowire: a platform for maturation of human pluripotent stem cell-derived cardiomyocytes. Nat Methods 10:781-787

Okita K, Matsumura Y, Sato Y, Okada A, Morizane A, Okamoto S, Hong H, Nakagawa M, Tanabe K, Tezuka K, Shibata T, Kunisada T, Takahashi M, Takahashi J, Saji H, Yamanaka S (2011) A more efficient method to generate integration-free human ips cells. Nat Methods 8:409-412

Onakpoya IJ, Heneghan CJ, Aronson JK (2016) Post-marketing withdrawal of 462 medicinal products because of adverse drug reactions: a systematic review of the world literature. BMC Med $14: 10$

Parikh SS, Blackwell DJ, Gomez-Hurtado N, Frisk M, Wang L, Kim K, Dahl CP, Fiane A, Tonnessen T, Kryshtal DO, Louch WE, Knollmann BC (2017) Thyroid and glucocorticoid hormones promote functional t-tubule development in human-induced pluripotent stem cell-derived cardiomyocytes. Circ Res 121:1323-1330

Porrello ER, Mahmoud AI, Simpson E, Hill JA, Richardson JA, Olson EN, Sadek HA (2011) Transient regenerative potential of the neonatal mouse heart. Science 331:1078-1080

Preininger MK, Jha R, Maxwell JT, Wu Q, Singh M, Wang B, Dalal A, McEachin ZT, Rossoll W, Hales CM, Fischbach PS, Wagner MB, Xu C (2016) A human pluripotent stem cell model of catecholaminergic polymorphic ventricular tachycardia recapitulates patient-specific drug responses. Dis Model Mech 9:927-939

Protze SI, Liu J, Nussinovitch U, Ohana L, Backx PH, Gepstein L, Keller GM (2017) Sinoatrial node cardiomyocytes derived from human pluripotent cells function as a biological pacemaker. Nat Biotechnol 35:56-68

Protze SI, Lee JH, Keller GM (2019) Human pluripotent stem cellderived cardiovascular cells: From developmental biology to therapeutic applications. Cell Stem Cell 25:311-327

Puente BN, Kimura W, Muralidhar SA, Moon J, Amatruda JF, Phelps KL, Grinsfelder D, Rothermel BA, Chen R, Garcia JA, Santos CX, Thet S, Mori E, Kinter MT, Rindler PM, Zacchigna S, Mukherjee S, Chen DJ, Mahmoud AI, Giacca M, Rabinovitch PS, Aroumougame A, Shah AM, Szweda LI, Sadek HA (2014) The oxygen-rich postnatal environment induces cardiomyocyte cell-cycle arrest through DNA damage response. Cell 157:565-579

Reichart D, Magnussen C, Zeller T, Blankenberg S (2019) Dilated cardiomyopathy: from epidemiologic to genetic phenotypes: a translational review of current literature. J Intern Med 286:362-372

Rog-Zielinska EA, Richardson RV, Denvir MA, Chapman KE (2014) Glucocorticoids and foetal heart maturation; implications for prematurity and foetal programming. J Mol Endocrinol 52:R125-135

Rog-Zielinska EA, Craig MA, Manning JR, Richardson RV, Gowans GJ, Dunbar DR, Gharbi K, Kenyon CJ, Holmes MC, Hardie DG, Smith GL, Chapman KE (2015) Glucocorticoids promote structural and functional maturation of foetal cardiomyocytes: a role for pgc-1alpha. Cell Death Differ 22:1106-1116

Romagnuolo R, Masoudpour H, Porta-Sanchez A, Qiang B, Barry J, Laskary A, Qi X, Masse S, Magtibay K, Kawajiri H, Wu J, Valdman Sadikov T, Rothberg J, Panchalingam KM, Titus E, Li RK, Zandstra PW, Wright GA, Nanthakumar K, Ghugre NR, Keller G, Laflamme MA (2019) Human embryonic stem cell-derived cardiomyocytes regenerate the infarcted pig heart but induce ventricular tachyarrhythmias. Stem Cell Rep 12:967-981

Ronaldson-Bouchard K, Ma SP, Yeager K, Chen T, Song L, Sirabella D, Morikawa K, Teles D, Yazawa M, Vunjak-Novakovic $\mathrm{G}$ (2018) Advanced maturation of human cardiac tissue grown from pluripotent stem cells. Nature 556:239-243 
Sakamoto T, Matsuura TR, Wan S, Ryba DM, Kim JU, Won KJ, Lai L, Petucci C, Petrenko N, Musunuru K, Vega RB, Kelly DP (2020) A critical role for estrogen-related receptor signaling in cardiac maturation. Circ Res 126:1685-1702

Sasaki K, Makiyama T, Yoshida Y, Wuriyanghai Y, Kamakura T, Nishiuchi S, Hayano M, Harita T, Yamamoto Y, Kohjitani H, Hirose S, Chen J, Kawamura M, Ohno S, Itoh H, Takeuchi A, Matsuoka S, Miura M, Sumitomo N, Horie M, Yamanaka S, Kimura T (2016) Patient-specific human induced pluripotent stem cell model assessed with electrical pacing validates s107 as a potential therapeutic agent for catecholaminergic polymorphic ventricular tachycardia. PLoS ONE 11:e0164795

Schultheiss HP, Fairweather D, Caforio ALP, Escher F, Hershberger RE, Lipshultz SE, Liu PP, Matsumori A, Mazzanti A, McMurray J, Priori SG (2019) Dilated cardiomyopathy. Nat Rev Dis Primers 5:32

Schwartz PJ, Crotti L, Insolia R (2012) Long-qt syndrome: from genetics to management. Circ Arrhythm Electrophysiol 5:868-877

Schwartz PJ, Gnecchi M, Dagradi F, Castelletti S, Parati G, Spazzolini C, Sala L, Crotti L (2019) From patient-specific induced pluripotent stem cells to clinical translation in long qt syndrome type 2. Eur Heart J 40:1832-1836

Seki T, Yuasa S, Oda M, Egashira T, Yae K, Kusumoto D, Nakata H, Tohyama S, Hashimoto H, Kodaira M, Okada Y, Seimiya H, Fusaki N, Hasegawa M, Fukuda K (2010) Generation of induced pluripotent stem cells from human terminally differentiated circulating t cells. Cell Stem Cell 7:11-14

Sekine H, Shimizu T, Dobashi I, Matsuura K, Hagiwara N, Takahashi M, Kobayashi E, Yamato M, Okano T (2011) Cardiac cell sheet transplantation improves damaged heart function via superior cell survival in comparison with dissociated cell injection. Tissue Eng Part A 17:2973-2980

Shafaattalab S, Lin E, Christidi E, Huang H, Nartiss Y, Garcia A, Lee J, Protze S, Keller G, Brunham L, Tibbits GF, Laksman Z (2019) Ibrutinib displays atrial-specific toxicity in human stem cellderived cardiomyocytes. Stem Cell Rep 12:996-1006

Shanks N, Greek R, Greek J (2009) Are animal models predictive for humans? Philos Ethics Humanit Med 4:2

Sharma A, Burridge PW, McKeithan WL, Serrano R, Shukla P, Sayed N, Churko JM, Kitani T, Wu H, Holmstrom A, Matsa E, Zhang Y, Kumar A, Fan AC, Del Alamo JC, Wu SM, Moslehi JJ, Mercola M, Wu JC (2017) High-throughput screening of tyrosine kinase inhibitor cardiotoxicity with human induced pluripotent stem cells. Sci Transl Med 9:eaaf2584

Shiba Y, Fernandes S, Zhu WZ, Filice D, Muskheli V, Kim J, Palpant NJ, Gantz J, Moyes KW, Reinecke H, Van Biber B, Dardas T, Mignone JL, Izawa A, Hanna R, Viswanathan M, Gold JD, Kotlikoff MI, Sarvazyan N, Kay MW, Murry CE, Laflamme MA (2012) Human es-cell-derived cardiomyocytes electrically couple and suppress arrhythmias in injured hearts. Nature 489:322-325

Shiba Y, Gomibuchi T, Seto T, Wada Y, Ichimura H, Tanaka Y, Ogasawara T, Okada K, Shiba N, Sakamoto K, Ido D, Shiina T, Ohkura M, Nakai J, Uno N, Kazuki Y, Oshimura M, Minami I, Ikeda U (2016) Allogeneic transplantation of ips cell-derived cardiomyocytes regenerates primate hearts. Nature 538:388-391

Silver D, Huang A, Maddison CJ, Guez A, Sifre L, van den Driessche G, Schrittwieser J, Antonoglou I, Panneershelvam V, Lanctot M, Dieleman S, Grewe D, Nham J, Kalchbrenner N, Sutskever I, Lillicrap T, Leach M, Kavukcuoglu K, Graepel T, Hassabis D (2016) Mastering the game of go with deep neural networks and tree search. Nature 529:484-489

Smith C, Gore A, Yan W, Abalde-Atristain L, Li Z, He C, Wang Y, Brodsky RA, Zhang K, Cheng L, Ye Z (2014) Whole-genome sequencing analysis reveals high specificity of crispr/cas9 and talen-based genome editing in human ipscs. Cell Stem Cell 15:12-13

Sommariva E, Brambilla S, Carbucicchio C, Gambini E, Meraviglia V, Dello Russo A, Farina FM, Casella M, Catto V, Pontone G, Chiesa M, Stadiotti I, Cogliati E, Paolin A, Ouali Alami N, Preziuso C, d'Amati G, Colombo GI, Rossini A, Capogrossi MC, Tondo C, Pompilio G (2016) Cardiac mesenchymal stromal cells are a source of adipocytes in arrhythmogenic cardiomyopathy. Eur Heart J 37:1835-1846

Sommariva E, Stadiotti I, Perrucci GL, Tondo C, Pompilio G (2017) Cell models of arrhythmogenic cardiomyopathy: advances and opportunities. Dis Model Mech 10:823-835

Stillitano F, Hansen J, Kong CW, Karakikes I, Funck-Brentano C, Geng L, Scott S, Reynier S, Wu M, Valogne Y, Desseaux C, Salem JE, Jeziorowska D, Zahr N, Li R, Iyengar R, Hajjar RJ, Hulot JS (2017) Modeling susceptibility to drug-induced long qt with a panel of subject-specific induced pluripotent stem cells. Elife 6:e19406

Sun N, Yazawa M, Liu J, Han L, Sanchez-Freire V, Abilez OJ, Navarrete EG, Hu S, Wang L, Lee A, Pavlovic A, Lin S, Chen R, Hajjar RJ, Snyder MP, Dolmetsch RE, Butte MJ, Ashley EA, Longaker MT, Robbins RC, Wu JC (2012) Patient-specific induced pluripotent stem cells as a model for familial dilated cardiomyopathy. Sci Transl Med. 4:130ra147

Suzuki K, Yu C, Qu J, Li M, Yao X, Yuan T, Goebl A, Tang S, Ren R, Aizawa E, Zhang F, Xu X, Soligalla RD, Chen F, Kim J, Kim NY, Liao HK, Benner C, Esteban CR, Jin Y, Liu GH, Li Y, Izpisua Belmonte JC (2014) Targeted gene correction minimally impacts whole-genome mutational load in human-diseasespecific induced pluripotent stem cell clones. Cell Stem Cell 15:31-36

Takahashi K, Yamanaka S (2006) Induction of pluripotent stem cells from mouse embryonic and adult fibroblast cultures by defined factors. Cell 126:663-676

Takahashi K, Tanabe K, Ohnuki M, Narita M, Ichisaka T, Tomoda $\mathrm{K}$, Yamanaka S (2007) Induction of pluripotent stem cells from adult human fibroblasts by defined factors. Cell 131:861-872

Takaki T, Inagaki A, Chonabayashi K, Inoue K, Miki K, Ohno S, Makiyama T, Horie M, Yoshida Y (2019) Optical recording of action potentials in human induced pluripotent stem cell-derived cardiac single cells and monolayers generated from long qt syndrome type 1 patients. Stem Cells Int 2019:7532657

Tanaka A, Yuasa S, Mearini G, Egashira T, Seki T, Kodaira M, Kusumoto D, Kuroda Y, Okata S, Suzuki T, Inohara T, Arimura T, Makino S, Kimura K, Kimura A, Furukawa T, Carrier L, Node K, Fukuda K (2014) Endothelin-1 induces myofibrillar disarray and contractile vector variability in hypertrophic cardiomyopathy-induced pluripotent stem cell-derived cardiomyocytes. J Am Heart Assoc 3:e001263

Theodoris CV, Zhou P, Liu L, Zhang Y, Nishino T, Huang Y, Kostina A, Ranade SS, Gifford CA, Uspenskiy V, Malashicheva A, Ding S, Srivastava D (2021) Network-based screen in ipsc-derived cells reveals therapeutic candidate for heart valve disease. Science 371 :eabd0724

Thiene G (2015) The research venture in arrhythmogenic right ventricular cardiomyopathy: a paradigm of translational medicine. Eur Heart J 36:837-846

Toepfer CN, Garfinkel AC, Venturini G, Wakimoto H, Repetti G, Alamo L, Sharma A, Agarwal R, Ewoldt JF, Cloonan P, Letendre J, Lun M, Olivotto I, Colan S, Ashley E, Jacoby D, Michels M, Redwood CS, Watkins HC, Day SM, Staples JF, Padron R, Chopra A, Ho CY, Chen CS, Pereira AC, Seidman JG, Seidman CE (2020) Myosin sequestration regulates sarcomere function, cardiomyocyte energetics, and metabolism, informing the pathogenesis of hypertrophic cardiomyopathy. Circulation 141:828-842 
Tohyama S, Hattori F, Sano M, Hishiki T, Nagahata Y, Matsuura T, Hashimoto H, Suzuki T, Yamashita H, Satoh Y, Egashira T, Seki T, Muraoka N, Yamakawa H, Ohgino Y, Tanaka T, Yoichi M, Yuasa S, Murata M, Suematsu M, Fukuda K (2013) Distinct metabolic flow enables large-scale purification of mouse and human pluripotent stem cell-derived cardiomyocytes. Cell Stem Cell 12:127-137

Uosaki H, Fukushima H, Takeuchi A, Matsuoka S, Nakatsuji N, Yamanaka S, Yamashita JK (2011) Efficient and scalable purification of cardiomyocytes from human embryonic and induced pluripotent stem cells by vcam 1 surface expression. PLoS ONE 6:e23657

Veres A, Gosis BS, Ding Q, Collins R, Ragavendran A, Brand H, Erdin S, Cowan CA, Talkowski ME, Musunuru K (2014) Low incidence of off-target mutations in individual crispr-cas9 and talen targeted human stem cell clones detected by whole-genome sequencing. Cell Stem Cell 15:27-30

Wang Y, Liang P, Lan F, Wu H, Lisowski L, Gu M, Hu S, Kay MA, Urnov FD, Shinnawi R, Gold JD, Gepstein L, Wu JC (2014a) Genome editing of isogenic human induced pluripotent stem cells recapitulates long qt phenotype for drug testing. J Am Coll Cardiol 64:451-459

Wang G, McCain ML, Yang L, He A, Pasqualini FS, Agarwal A, Yuan H, Jiang D, Zhang D, Zangi L, Geva J, Roberts AE, Ma Q, Ding J, Chen J, Wang DZ, Li K, Wang J, Wanders RJ, Kulik W, Vaz FM, Laflamme MA, Murry CE, Chien KR, Kelley RI, Church GM, Parker KK, Pu WT (2014b) Modeling the mitochondrial cardiomyopathy of Barth syndrome with induced pluripotent stem cell and heart-on-chip technologies. Nat Med 20:616-623

Wang Y, Yao F, Wang L, Li Z, Ren Z, Li D, Zhang M, Han L, Wang SQ, Zhou B, Wang L (2020) Single-cell analysis of murine fibroblasts identifies neonatal to adult switching that regulates cardiomyocyte maturation. Nat Commun 11:2585

Webb S (2018) Deep learning for biology. Nature 554:555-557

Wilde AAM, Amin AS, Postema PG (2021) Diagnosis, management and therapeutic strategies for congenital long qt syndrome. Heart 2020:318259

Witty AD, Mihic A, Tam RY, Fisher SA, Mikryukov A, Shoichet MS, Li RK, Kattman SJ, Keller G (2014) Generation of the epicardial lineage from human pluripotent stem cells. Nat Biotechnol 32:1026-1035

Woltjen K, Michael IP, Mohseni P, Desai R, Mileikovsky M, Hamalainen R, Cowling R, Wang W, Liu P, Gertsenstein M, Kaji K, Sung HK, Nagy A (2009) Piggybac transposition reprograms fibroblasts to induced pluripotent stem cells. Nature 458:766-770

Yamazaki D, Kitaguchi T, Ishimura M, Taniguchi T, Yamanishi A, Saji D, Takahashi E, Oguchi M, Moriyama Y, Maeda S, Miyamoto K, Morimura K, Ohnaka H, Tashibu H, Sekino Y, Miyamoto N, Kanda Y (2018) Proarrhythmia risk prediction using human induced pluripotent stem cell-derived cardiomyocytes. J Pharmacol Sci 136:249-256

Yang L, Soonpaa MH, Adler ED, Roepke TK, Kattman SJ, Kennedy M, Henckaerts E, Bonham K, Abbott GW, Linden RM, Field LJ, Keller GM (2008) Human cardiovascular progenitor cells develop from a kdr+ embryonic-stem-cell-derived population. Nature 453:524-528

Yang X, Rodriguez M, Pabon L, Fischer KA, Reinecke H, Regnier M, Sniadecki NJ, Ruohola-Baker H, Murry CE (2014)
Tri-iodo-1-thyronine promotes the maturation of human cardiomyocytes-derived from induced pluripotent stem cells. J Mol Cell Cardiol 72:296-304

Yang KC, Breitbart A, De Lange WJ, Hofsteen P, Futakuchi-Tsuchida A, Xu J, Schopf C, Razumova MV, Jiao A, Boucek R, Pabon L, Reinecke H, Kim DH, Ralphe JC, Regnier M, Murry CE (2018) Novel adult-onset systolic cardiomyopathy due to myh7 e848g mutation in patient-derived induced pluripotent stem cells. JACC Basic Transl Sci 3:728-740

Yang X, Rodriguez ML, Leonard A, Sun L, Fischer KA, Wang Y, Ritterhoff J, Zhao L, Kolwicz SC Jr, Pabon L, Reinecke H, Sniadecki NJ, Tian R, Ruohola-Baker H, Xu H, Murry CE (2019) Fatty acids enhance the maturation of cardiomyocytes derived from human pluripotent stem cells. Stem Cell Rep 13:657-668

Yang L, Han Y, Jaffre F, Nilsson-Payant BE, Bram Y, Wang P, Zhu J, Zhang T, Redmond D, Houghton S, Uhl S, Borczuk A, Huang Y, Richardson C, Chandar V, Acklin JA, Lim JK, Chen Z, Xiang J, Ho DD, tenOever BR, Schwartz RE, Evans T, Chen S (2021) An immuno-cardiac model for macrophage-mediated inflammation in covid-19 hearts. Circ Res 129:33-46

Yu J, Hu K, Smuga-Otto K, Tian S, Stewart R, Slukvin II, Thomson JA (2009) Human induced pluripotent stem cells free of vector and transgene sequences. Science 324:797-801

Yuan P, Cheedipudi SM, Rouhi L, Fan S, Simon L, Zhao Z, Hong K, Gurha P, Marian AJ (2021) Single-cell rna sequencing uncovers paracrine functions of the epicardial-derived cells in arrhythmogenic cardiomyopathy. Circulation 143:2169-2187

Zhang Q, Jiang J, Han P, Yuan Q, Zhang J, Zhang X, Xu Y, Cao H, Meng Q, Chen L, Tian T, Wang X, Li P, Hescheler J, Ji G, Ma Y (2011) Direct differentiation of atrial and ventricular myocytes from human embryonic stem cells by alternating retinoid signals. Cell Res 21:579-587

Zhang H, Lui KO, Zhou B (2018) Endocardial cell plasticity in cardiac development, diseases and regeneration. Circ Res 122:774-789

Zhang H, Tian L, Shen M, Tu C, Wu H, Gu M, Paik DT, Wu JC (2019a) Generation of quiescent cardiac fibroblasts from human induced pluripotent stem cells for in vitro modeling of cardiac fibrosis. Circ Res 125:552-566

Zhang JZ, Termglinchan V, Shao NY, Itzhaki I, Liu C, Ma N, Tian L, Wang VY, Chang ACY, Guo H, Kitani T, Wu H, Lam CK, Kodo K, Sayed N, Blau HM, Wu JC (2019b) A human ipsc doublereporter system enables purification of cardiac lineage subpopulations with distinct function and drug response profiles. Cell Stem Cell 24:802-811 e805

Zhao Y, Rafatian N, Feric NT, Cox BJ, Aschar-Sobbi R, Wang EY, Aggarwal P, Zhang B, Conant G, Ronaldson-Bouchard K, Pahnke A, Protze S, Lee JH, Davenport Huyer L, Jekic D, Wickeler A, Naguib HE, Keller GM, Vunjak-Novakovic G, Broeckel U, Backx PH, Radisic M (2019) A platform for generation of chamber-specific cardiac tissues and disease modeling. Cell 176:913-927 e918

Publisher's Note Springer Nature remains neutral with regard to jurisdictional claims in published maps and institutional affiliations. 